\title{
Covid-19 Partisanship in the UK: Findings from Survey and
}

\section{Mobility Data}

\author{
Tim Vlandas ${ }^{1} \quad$ Margaryta Klymak ${ }^{2 *}$ \\ ${ }^{1}$ University of Oxford \\ ${ }^{2}$ University of Oxford
}

October 28, 2021

\begin{abstract}
What is relationship between partisanship and views and behaviours towards Covid19? This article tackles this research question using nearly 100,000 survey responses to a new and highly granular daily survey as well as google mobility matched to UK general election data. Our results suggest that partisanship is correlated with the views and behaviours of different voters. First, Conservatives saw Covid-19 as less threatening than Labour voters and they tended to leave home more after the national lockdown was announced, even after controlling for potential confounding factors. Second, random forests shows that partisanship was one of the most important predictor of attitudes and behaviours towards Covid-19. Third, the effect of national lockdown on mobility was negative and statistically significant only in less Conservative counties. Thus, partisanship is important to understand the views and behaviours of individuals during a pandemic.
\end{abstract}

\footnotetext{
*Vlandas: tim.vlandas@spi.ox.ac.uk, Department of Social Policy and Intervention, St Antony's College, University of Oxford. Klymak: Somerville College, Department of Economics, University of Oxford.
} 


\section{Introduction}

Covid-19 has led to nearly 4.5 million deaths worldwide (World Health Organization, 2021) with profound economic, political and social consequences. Yet, we still know comparatively little about whether and how views of Covid-19 and behaviours during the pandemic may have been shaped by partisan divides. In this article, we examine the extent to which partisanship shapes people's perceptions of the threat the pandemic poses and how this affects their behaviour and compliance with the national lockdown measures.

Understanding the relationship between partisanship and attitudes as well as behaviours towards pandemic is important for two reasons. ${ }^{1}$ First, in the short term if perceptions of Covid-19 differ strongly depending on pre-existing party preferences, partisan divisions in societies might undermine the ability of governments to effectively address the pandemic crisis: certain voters may hold systematically distinct beliefs making them reluctant to follow government policies, precisely at a time where concerted and decisive collective action is most needed. As a result, there is a risk that partisanship undermines government's policy response to Covid-19, by making certain individuals sceptical of the threat posed by Covid-19 or reluctant to reduce their social interactions and mobility. Second, in the medium to long term the effect of the Covid-19 shock on the distribution of economic and health risks may further divide nations along partisan lines, thereby leading to increased political polarization, which might destabilize democracies and their economies.

The UK presents an ideal case to analyse the degree to which partisanship accounts for individual differences across distinct dimensions of Covid-19 perceptions, attitudes, and behaviours for two reasons. First, the country is highly polarised and the extent to which the

\footnotetext{
${ }^{1}$ This short empirical article cannot do justice to the large emerging literature on Covid-19 nor provide a full theorisation of the complex relationship between partisanship and pandemics. Please see reviews of recent research in political sciences (Devine et al., 2020) and in economics (Brodeur et al., 2021).
} 
UK is driven by partisan dynamics has been widely discussed in previous literature (Evans and Neundorf, 2020; Cohen and Cohen, 2021), but there are no studies to date investigating whether and how Covid-19 affects these divisions. Second, this gap is surprising because the UK has over 7.3 million confirmed cases and more than 135,000 deaths (World Health Organization, 2021), making it one of the countries most affected by the Covid-19 pandemic (Roser, 2020). To the extent that the pandemic adversely affects different segments of the population in distinct ways, this represents a good case to assess how societies' partisan polarisation is affected by large shocks.

Moreover, like other governments across the world, the UK implemented a strict national lockdown in March 2020 (Cameron-Blake et al., 2020). Yet, there is still limited evidence on how partisanship may have influenced how individuals perceived these interventions, and whether these perceptions in turn affected their behaviours during the lockdown. Theoretically, the effect of partisanship on the Covid-19 views and behaviours of different voter groups appears a priori indeterminate in the UK. On the one hand, if right leaning in individuals in the UK hold similar views and behaviours as their Republican counterparts in the US (Clinton et al., 2021; Allcott et al., 2020), we could expect Conservative voters to be more sceptic of the pandemic and more likely to continue being mobile during the lockdown. On the other hand, there is no a priori reason for right-wing individuals to be more sceptic, nor adopt more risky behaviours, than left-wing individuals. The lockdown in the US and the UK were rather different, and UK Conservatives could also be especially responsive to the views and policies of a Conservative government they helped elect and with which they likely identify. Finally, some studies have also found that the British Public has "depolarized" politically (Adams, Green and Milazzo, 2012).

To explore partisan differences in the UK across a wide range of attitudes, perceptions and behaviours, we adopt two complementary empirical approaches by providing a wide range of correlational evidence at two levels of analyses. First, we analyse a uniquely geographically 
granular daily survey of nearly 100,000 respondents in the early period of the pandemic in the UK. This novel survey includes a large number of questions, most notably about party identification and a wide range of Covid-19 attitudes and behaviours. We use linear probability models and a machine learning approach to explore empirically the relationship between these individual attitudes and behaviours as well as partisan affiliation. Second, we match anonymised Google mobility data throughout 2020 and information about the share of the population that voted for different political parties across UK counties in the latest national election. We leverage the announcement of the national lockdown to examine its effect on changes in mobility, before and during the lockdown, for counties with different electoral results.

Our findings show that Conservative voters hold more sceptic views of Covid-19 and were less likely to reduce their mobility during the national lockdown. Specifically, Conservative voters are more likely to think that Covid-19 is no more dangerous than a flu and that it is taken too seriously, and they are less likely to fear they will get infected but more likely to think they will recover if they become infected. These results provide an interesting parallel to studies on the US, where political polarisation has received significant attention (Hetherington, 2009; Lupton, Smallpage and Enders, 2020) and partisanship has recently been found to be one particularly strong driver of individual differences in compliance (Gollwitzer et al., 2020; Clinton et al., 2021; Allcott et al., 2020; Grossman et al., 2020): Republicans tend to perceive Covid-19 as a more minor health threat than Democrats and are also less likely to follow social distancing rules and to wear masks. We provide evidence across wide range of dimensions and using different datasets that a similar partisan dynamic can be observed in the UK.

\section{Survey analysis}

Our individual level analysis relies on a survey collected daily between 25th of March and 18th of May 2020 by YouGov. It is a repeated representative cross-section of the UK 
population with a sample size totalling over 100,000 respondents. Our data therefore begins in March with the announcement of a national lockdown by UK Prime Minister Boris Johnson. We focus on six questions to capture attitudes and behaviours during Covid-19. Two questions are about the likelihood of catching and recovering from Covid-19. Another two questions are about whether Covid-19 is taken seriously enough and whether it will cause more deaths than a normal flu. The remaining two questions deal with behaviour: whether the respondent left their home for any reason at all and to what degree they have self-isolated. ${ }^{2}$ To identify partisan affiliation, we use the following survey question: "Generally speaking, do you think of yourself as Labour, Conservative, Liberal Democrat or what?" and gives respondents the following options: Conservative, Green, Labour, Liberal Democrat, SNP, UKIP, None or Other.

We present the daily average response for Labour and Conservative voters for our six key variables in Figure 1. We plot daily average responses (with $95 \%$ confidence interval) for four attitudinal and two behavioural variables as the pandemic enfolded. Conservative voters exhibit lower perceptions of the risk of catching Covid-19. Labour voters' perception of this risk fell between mid-March and the end of April, at which point the Prime Minister declared that the UK had passed the peak of the pandemic. By contrast, Conservative voters' self-reported likelihood of catching Covid-19 fell continuously and only stabilized from mid-May onwards. Throughout the period under consideration, the gap between the two groups of voters remained above 15 percentage points.

Moreover, the average difference between Labour and Conservative voters in the self-reported confidence that one would recover from Covid-19 appeared small in the initial phase of the pandemic from March to mid-April. Next, we can observe substantial and growing partisan differences in wider views about Covid-19 fatalities. Conservative voters were systematically

\footnotetext{
${ }^{2}$ See section A in supplementary material for specific wording of questions.
} 
more optimistic than Labour about whether Covid-19 represented a unique and significant health threat. Indeed, in late March 2020, nearly 50\% of Conservatives did not think that Covid-19 would cause more deaths than normal flu. This optimism has tended to fall in tandem for both groups of voters in late March, as the pandemic enfolded, and the UK entered the national lockdown. This partisan divergence over time can also be observed in other survey questions about whether Covid-19 is taken seriously enough: a majority of both Labour and Conservative voters initially thought it was not taken seriously enough, but this then fell for Conservatives much more than Labour. ${ }^{3}$

However, there are smaller partisan differences in terms of individual behaviours towards Covid-19. Indeed, there were comparatively smaller differences between Conservative and Labour voters in terms of their likelihood to leave their home and decision to self-isolate. Conservative voters reported a slightly higher daily average propensity to leave their home, but the gap with Labour voters was small, and the two groups of voters moved in tandem over time. As the pandemic enfolded, voters appeared to be progressively more likely to leave their home. To some extent, the rise towards the end of the period coincided with the announcement in May that lockdown was going to be lifted. Similarly, the gap in reported self-isolation between these two groups of voters was not substantial and most of the differences only grew over time. Labour voters reported marginally higher self-isolation, but the difference was small, while we can observe a fall in the share that self-isolate for both groups of voters, from above $25 \%$ to above $15 \%$.

The partisan differences we have observed so far could be due to systematic differences in work patterns and subjective health of respondents for different groups of voters. While theoretically plausible, we cannot observe empirically a larger share of Labour voters

\footnotetext{
${ }^{3}$ Similarly, a smaller share of Labour voters thought the Economy would bounce back quickly (Figure B.5 in supplementary material), and a much higher share of Labour voters feared for own future (15 percentage points difference Figure B.4 in supplementary material).
} 
working from home than is the case for Conservative voters (Figure B.1), nor is there a statistically significant difference between Conservative and Labour voters in terms of self-reported employment change due to Covid-19 once we control for 
Figure 1: Individual views and behaviour during Covid-19
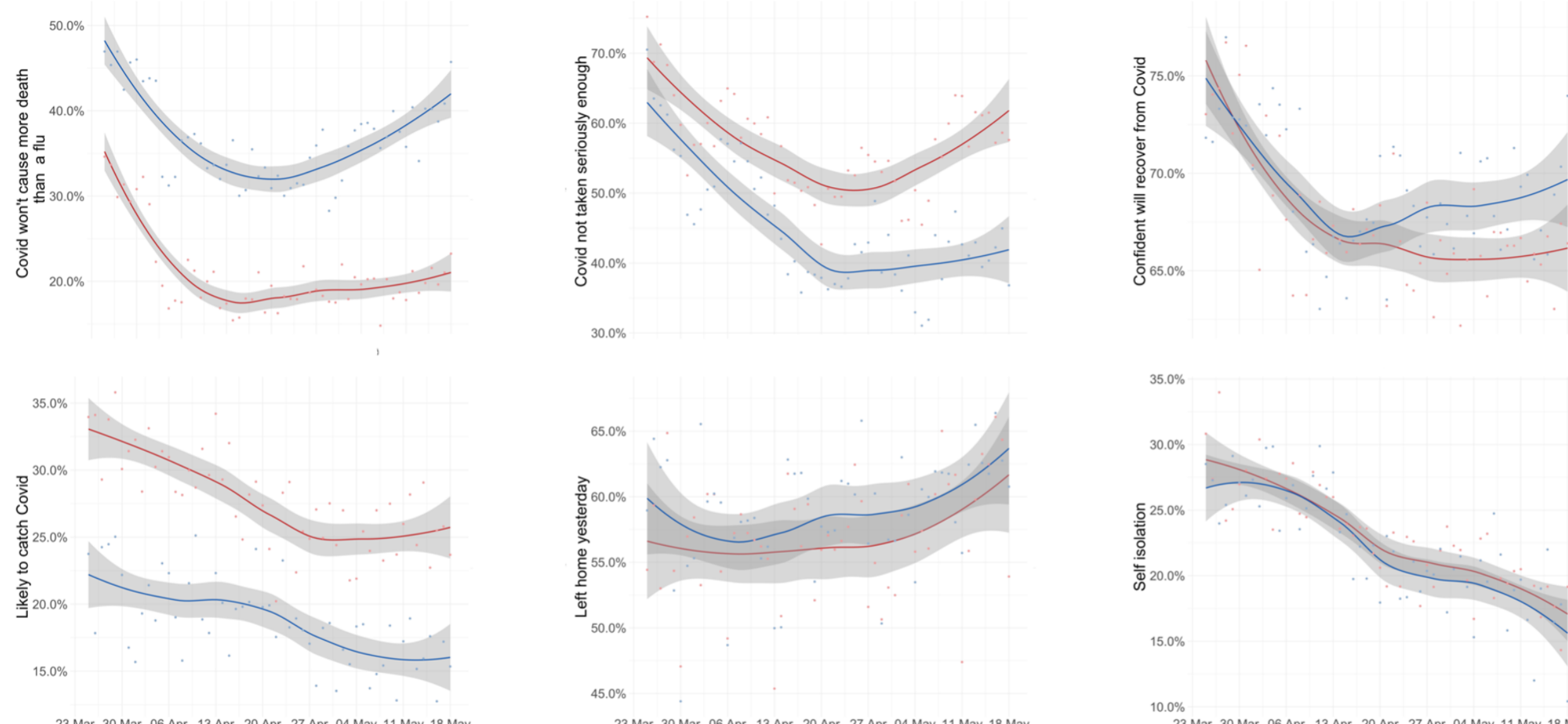

$$
30.0 \%
$$

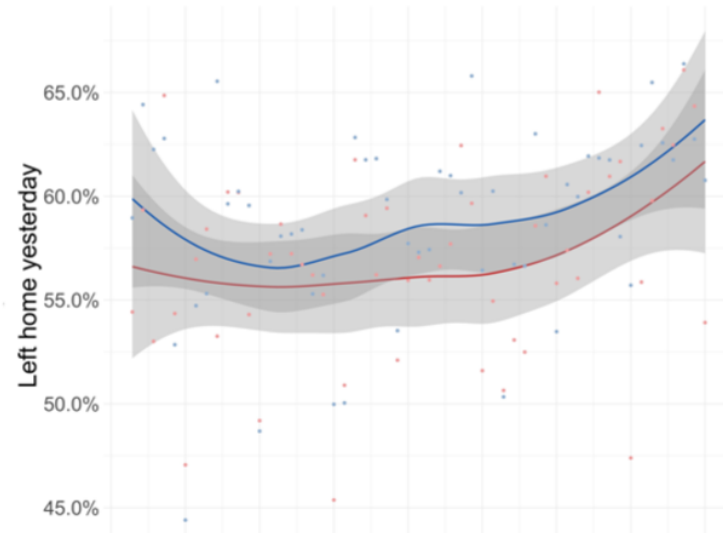

23 Mar 30 Mar 06 Apr 13 Apr 20 Apr
Date

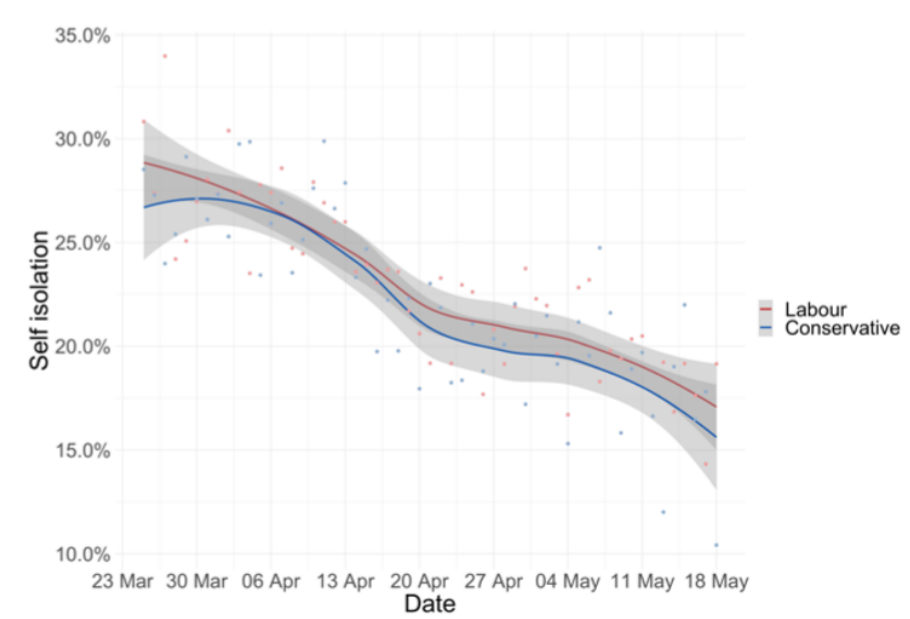

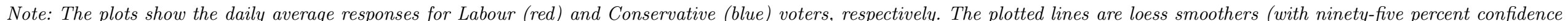
intervals). 
other factors (Figure B.2 and Figure C.6). However, the share of voters with self-assessed good health appeared stable over time and higher for Conservative than for Labour voters (Figure B.3 and Figure C.6).

Our empirical strategy aims to estimate whether a set of behavioural characteristics and beliefs can be explained by partisanship. We perform a series of linear probability regressions on our six dependent variables capturing individuals' perceptions of their vulnerability to catching and recovering from Covid-19, their views about societal responses to Covid-19, as well as their mobility. The key independent variable is the political party respondents identify with. Our main specification is as follows:

$$
\mathrm{y}_{i, r, t}=\alpha_{r}+\beta \text { Party }_{i, t}+\mathrm{PZ}_{i, t}+\phi \text { Covid Death }_{t}+\theta_{\mathrm{t}}+\theta_{t}^{2}+\mathrm{e}_{i, r, t}
$$

where $\mathrm{y}_{i, r, t}$ is the outcome of interest for an individual $i$ living in region $r$ at time $t$. Our empirical analysis includes six dependent variables: four are about respondents' views of pandemic and two are about their behaviours. The coefficient $\beta$ captures our main regressor of interest: it is coded 1 if the respondent voted for the Conservative party and 0 otherwise. We control for various individual time variant and time invariant characteristics, so that we do not - wrongly - attribute any findings to partisanship that are due to other differences between individuals. First, we control for a number of socio-economic and demographic attributes, $\mathrm{Z}_{i, t}$ : gender; age groups which include 18-24, 25-34, 45-54, 55-65, and 65+; education level which aggregates 18 different degree types into three levels (high, medium, or low); social grade based on the Social Grade system developed by the National Readership Survey; marital status; the number of children; and employment status which includes full-time, part-time, unemployed, student and retired. Table A.1 in supplementary material provides additional summary statistics for all the variables used in the empirical analysis. 
Second, we account for unobservable time invariant regional heterogeneity by including regional fixed effects $\alpha_{\mathrm{r}}{ }^{4}$ Third, we use data from the UK Office of National Statistics to control for the incidence of Covid-19 spread captured by the number of Covid-19 related death in the last 7 days in the UK prior to the interview of the respondent. Finally, we include a time trend $\theta_{t}$ and a quadratic trend $\theta_{t}^{2}$. We cluster the idiosyncratic standard errors $\mathrm{e}_{i, r, t}$ at the survey day-region levels. The model also uses appropriate survey weights.

Figure 2 plots the coefficients for Conservative voters (relative to other voters) ${ }^{5}$ for the six dependent variables, with and without controls, to illustrate whether and how much of the partisan differences disappear when we control for potential confounding factors. We find that Conservative voters are much more likely to think that Covid-19 is like a normal flu (12 percentage points lower) and less likely to think that it Covid-19 is not taken seriously enough. Being a Conservative voter is also positively correlated with being confident that one would recover well (5 percentage point higher) and significantly and negatively associated with having a higher perception of catching Covid-19 (5 percentage point higher). Finally, consistent with these more sceptic attitudes, Conservative voters are more likely to leave home than other voters. Although daily averages appeared to suggest that Conservative voters were less likely to self-isolate, this relationship is not statistically significant.

\footnotetext{
${ }^{4}$ Note that the dataset includes 148 regions.

${ }^{5}$ Note that in supplementary material we also present results with Labour voters as compared to Conservative voters.
} 
Figure 2: Attitudes and behaviours related to Covid-19 for Conservative voters

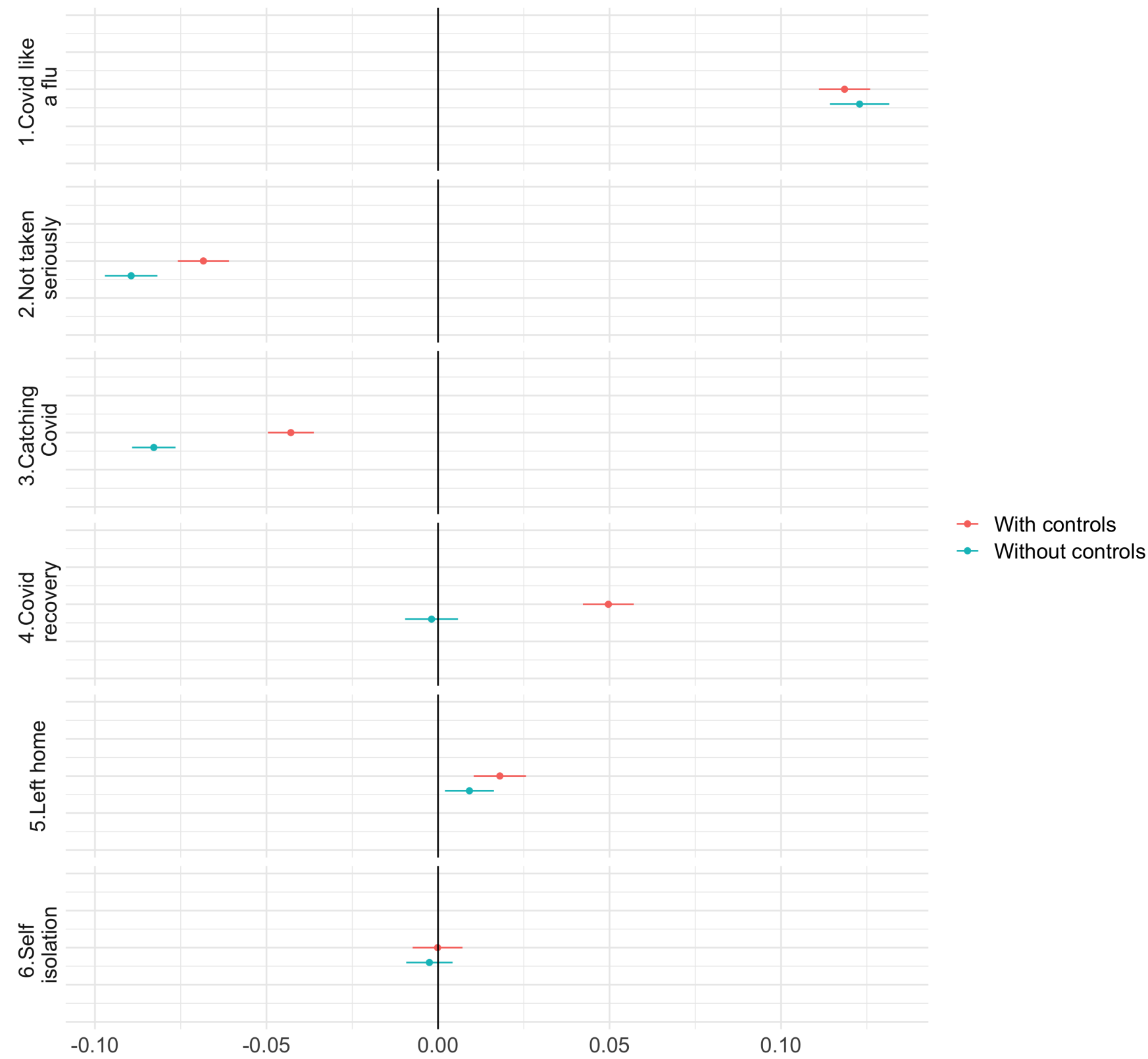

Note: The plot shows the coefficients (with 95\% confidence intervals) capturing the effect of being a Conservative voter (as compared to other voters), extracted from regressions of attitudes and behaviours towards Covid-19 on partisanship. The results that include all parties as compared to Conservative voters are reported in tables C.3 and C.4 in the supplementary material.

To assess the predictive power of partisanship relative to other individual characteristics, we adopt a machine learning approach using the random forests method (Breiman, 2001). 
We follow the standard procedure described in section $\mathrm{E}$ of supplementary material to determine the importance of each variable. Specifically, we use this method to explore the importance of partisanship relative to other individual factors, and identify the factors that most strongly predict Covid-19 related beliefs and behaviours.

The results are presented in Figure 3, which reports the importance of partisanship computed by random forests. We display both the mean decrease in accuracy, which estimates the improvements in the accuracy of the random forest prediction for each variable, and the mean decrease in Gini, which takes into account both improvements in accuracy and the degree of misclassification. We find strong evidence that partisanship is one of the most important variables to predict Covid-19 related beliefs and behaviours. When focusing on mean decrease in accuracy, partisanship is in the top 3 strongest predictors of respondents thinking that Covid-19 is like a normal flu, not taken seriously enough, and the estimated likelihood of recovery. When focusing on the mean decrease in Gini, partisanship is in the top 3 most important variables for all six dependent variables. 
Figure 3: Random forest results of the rank of partisanship among most important features
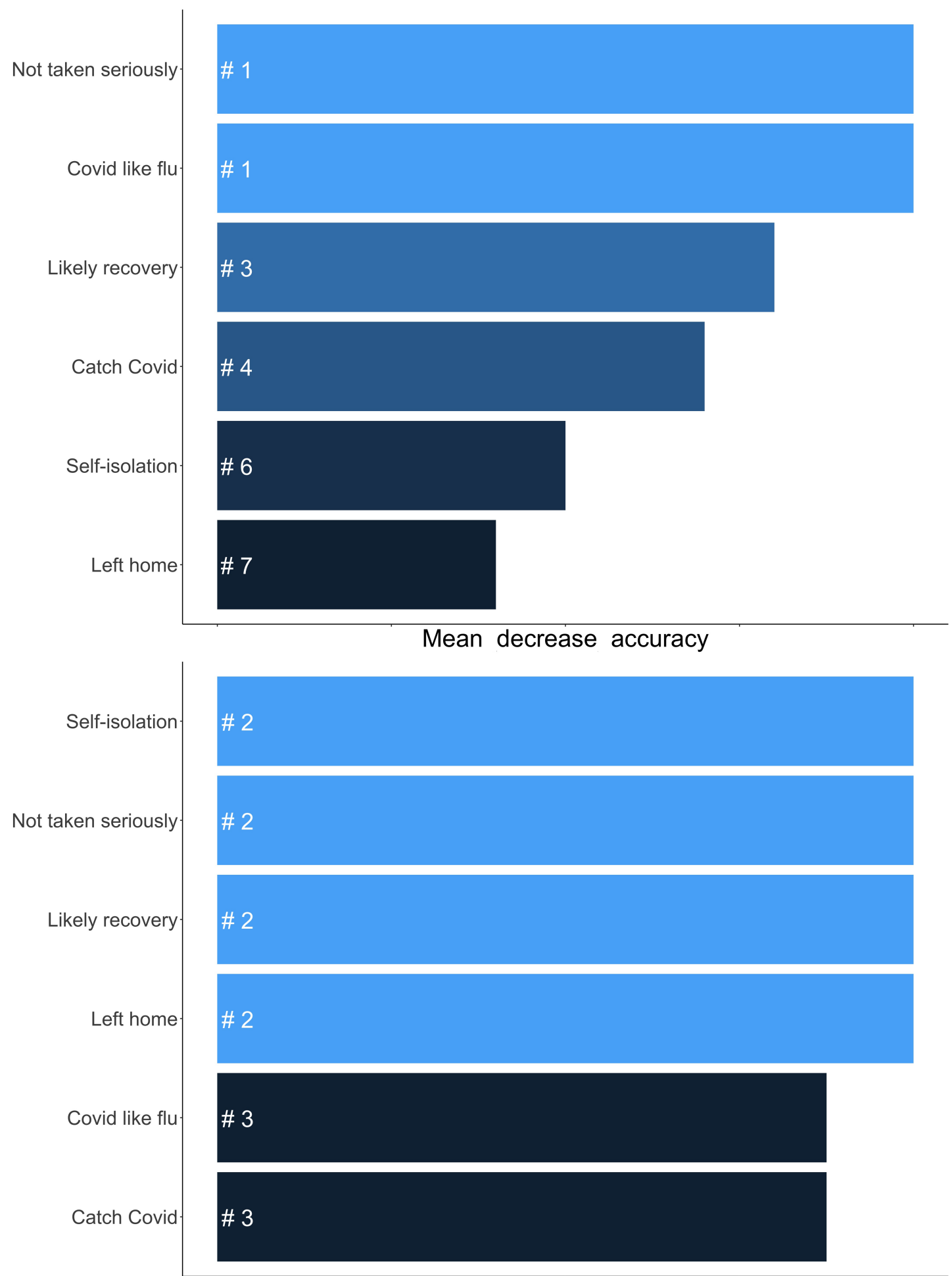

Mean decrease GINI

Note: The top panel presents results from mean decrease accuracy and the bottom panel depicts ranking from mean decrease in Gini. 


\section{Mobility analysis}

While valuable in its temporal and dimensional granularity, individual level data might suffer from social desirability bias as it does not directly measure behaviour, but merely asks respondents to declare their views and behaviours. To address these shortcomings of a survey approach, we complement our analysis with an extensive county level mobility analysis. We match the Google Mobility dataset covering the period from February to December 2020 with information about 2019 General Electoral Results for each UK county. Excluding weekends and public holidays from our dataset yields 300 days of mobility information in slightly under 50 sub-regions across England. ${ }^{6}$ The main specification is the following:

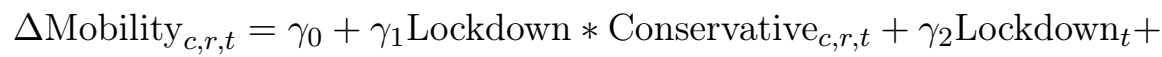

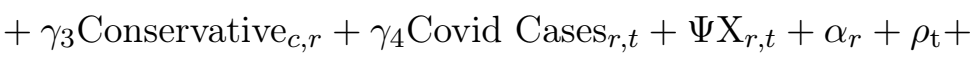

$$
\begin{aligned}
& +\rho_{t}^{2}+\varepsilon_{c, r, t}
\end{aligned}
$$

The dependent variable in this model is the differenced workplace mobility data, which was collected by Google. It measures how work attendance varies every day. ${ }^{7}$ We take the first difference of this variable to remove non stationarity. Our regressor of interest is the interaction term between a Lockdown dummy that takes value 0 before the announcement of the national lockdown in the UK on 23 March 2020, and 1 thereafter, and a variable measuring the percentage of Conservative votes in a particular county in England in the latest national election.

\footnotetext{
${ }^{6}$ Please see section A.3 in supplementary material for more information about the data sources and the matching procedures.

${ }^{7}$ Each daily measure is relative to the median value for the corresponding day of the average for the five-week period from 3rd January to 6th February 2020.
} 
We include several county level control variables $X_{r, t}$. These include three independent variables obtained from the Office of National Statistics: logarithms of population density, wages and house prices. Next, we control for ethnicity, captured as the percentage of people in a region who define their ethnicity as white, which we obtain from the House of Commons Library. In addition, we control for the logarithm of the number of Covid-19 related cases at the regional level. Finally, we include a trend $\rho_{t}$, its squared term $\rho_{t}^{2}$ and regional fixed effects, $\alpha_{r}$. We cluster the error term $\varepsilon_{c, r, t}$ at the day and region levels.

Fo reasons of space, the full regression results can only been shown in full in section D.7 of the supplementary material. The coefficient for Conservative share and lockdown are negative and statistically significant, while the coefficient for their interaction term is positive and statistically significant. These results suggest that the national lockdown was associated with a fall in google mobility indicator measuring movements to workplaces, as would be expected, but the size of effect was smaller in places with larger Conservative electorates. In Figure 4, we plot the average marginal effect of national lockdown on the change mobility conditional on the share of Conservative votes. The average marginal effect is negative and statistically significant in counties where the Conservative party received comparatively lower votes in the 2019 UK national election. By contrast, the marginal effect is not statistically significant in counties where the Conservative parties received comparatively more votes.

Moreover, replicating this analysis for different time windows in terms of the number of days included in the analysis (specifically 100, 125, 175, 200, 225, 250, 275 and 300 days) does not change the results (see table D.8 of supplementary material). In addition, we re-estimate the model for changes in transport mobility instead of workplace mobility. We find that the lockdown was associated with less mobility only in counties where the Conservative party did not receive a large share of votes (Figure D.8 in supplementary material). 
Figure 4: The effect of national lockdown on change in workplace mobility in counties with different levels of Conservative votes in previous national election

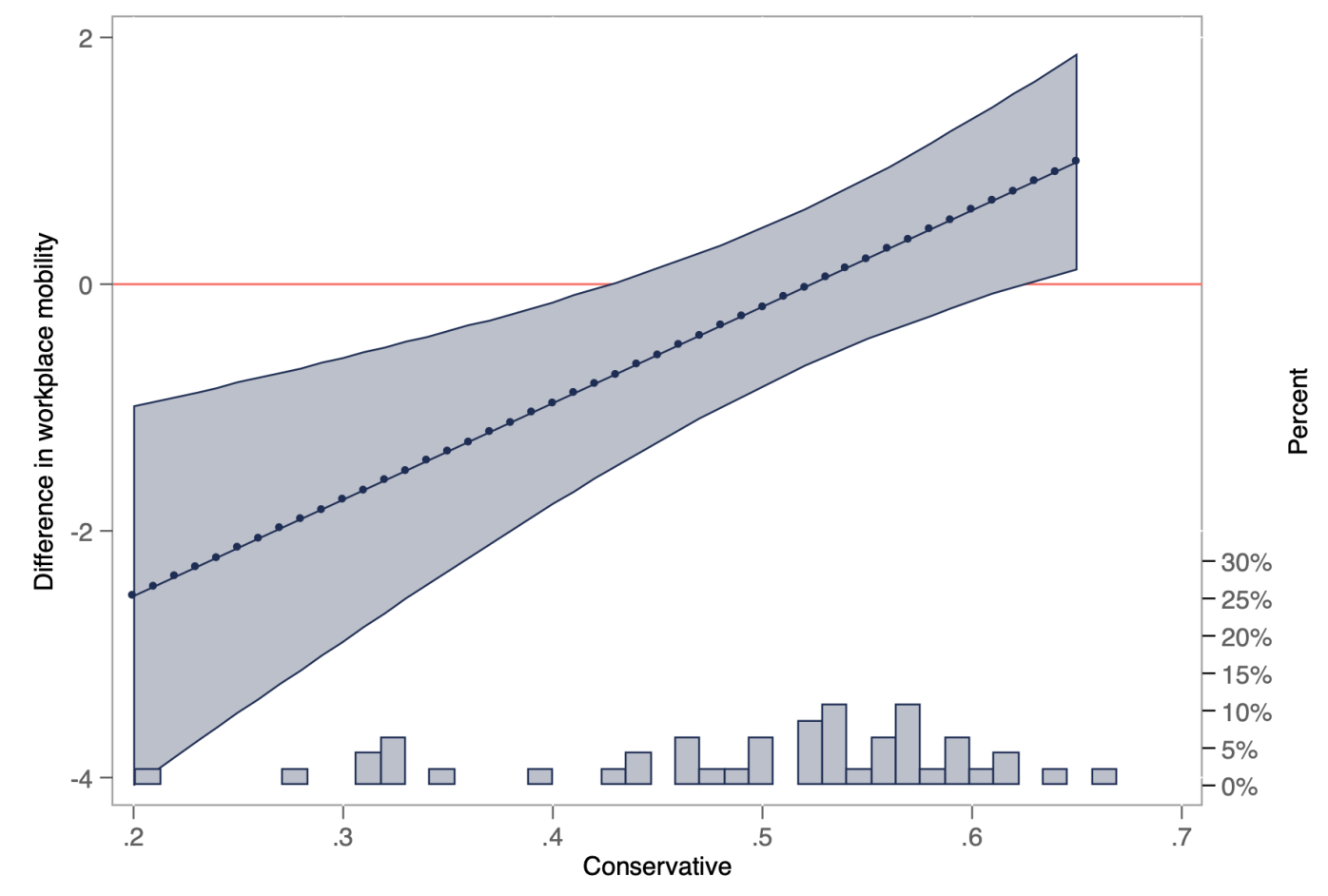

Note: This figure plots the average marginal effect of national lockdown on change in workplace mobility conditional on the Conservative vote share in counties in previous national election. The underlying coefficients are shown in column 3 in table D.7 in supplementary material and generated using the aforementioned model specification. Standard errors are clustered at day-region level.

\section{Conclusion}

In this article, we provide systematic evidence for the importance of partisanship in understanding the views and behaviours of the UK population towards Covid-19. Voters of different political parties appear to exhibit systematically different perceived risks of Covid-19 and they tend to behave differently when it comes to government policies and behaviours. While in principle one could speculate that partisan differences are due to the different socio-economic and demographic profiles of Conservative voters, our analysis makes clear that partisan differences remain even when controlling for differences in age, 
economic position, education, gender, family status, labour market status, and regional differences.

As was found in the case of US Republicans (Clinton et al., 2021), more right-leaning Conservative voters in the UK appear more sceptical of Covid-19 than Labour voters, who instead tend to find Covid-19 more dangerous for themselves, the economy and society at large. Similarly to the US case where Republicans were much more likely to believe that Covid-19 was less dangerous and also to behave in a way that increased the propagation of the virus, Conservative voters were more likely to remain mobile after national lockdown was announced. 


\section{References}

Adams, James, Jane Green, and Caitlin Milazzo. 2012. "Has the British public depolarized along with political elites? An American perspective on British public opinion." Comparative Political Studies, 45(4): 507-530.

Allcott, Hunt, Levi Boxell, Jacob Conway, Matthew Gentzkow, Michael Thaler, and David Yang. 2020. "Polarization and public health: Partisan differences in social distancing during the coronavirus pandemic." Journal of Public Economics, 191: 104254.

Breiman, Leo. 2001. "Random forests." Machine learning, 45(1): 5-32.

Brodeur, Abel, David Gray, Anik Islam, and Suraiya Bhuiyan. 2021. "A literature review of the economics of COVID-19." Journal of Economic Surveys, 35(4): 1007-1044.

Cameron-Blake, Emily, Helen Tatlow, Andrew Wood, Thomas Hale, Beatriz Kira, Anna Petherick, and Toby Phillips. 2020. "Variation in the response to COVID-19 across the four nations of the United Kingdom." Blavatnik School of Government, University of Oxford.

Clinton, Joshua, Jon Cohen, John Lapinski, and Marc Trussler. 2021. "Partisan pandemic: How partisanship and public health concerns affect individuals? social mobility during COVID-19." Science advances, 7(2): eabd7204.

Cohen, Gidon, and Sarah Cohen. 2021. "Depolarization, Repolarization and Redistributive Ideological Change in Britain, 1983-2016." British Journal of Political Science, 51(3): 1181-1202.

Devine, Daniel, Jennifer Gaskell, Will Jennings, and Gerry Stoker. 2020. "Trust and the Coronavirus Pandemic: What are the Consequences of and for Trust? An Early Review of the Literature." Political Studies Review, 1478929920948684.

Evans, Geoffrey, and Anja Neundorf. 2020. "Core political values and the long-term shaping of partisanship." British Journal of Political Science, 50(4): 1263-1281. 
Gollwitzer, Anton, Cameron Martel, William J Brady, Philip Pärnamets, Isaac G Freedman, Eric D Knowles, and Jay J Van Bavel. 2020. "Partisan differences in physical distancing are linked to health outcomes during the COVID-19 pandemic." Nature human behaviour, 4(11): 1186-1197.

Grossman, Guy, Soojong Kim, Jonah M Rexer, and Harsha Thirumurthy. 2020. "Political partisanship influences behavioral responses to governors? recommendations for COVID-19 prevention in the United States." Proceedings of the National Academy of Sciences, 117(39): 24144-24153.

Hetherington, Marc J. 2009. "Putting polarization in perspective." British Journal of Political Science, 39(2): 413-448.

Lupton, Robert N, Steven M Smallpage, and Adam M Enders. 2020. "Values and political predispositions in the age of polarization: Examining the relationship between partisanship and ideology in the United States, 1988-2012." British Journal of Political Science, 50(1): 241-260.

Roser, M. 2020. "Coronavirus Pandemic (COVID-19)." OurWorldInData.org.

World Health Organization. 2021. "COVID-19 weekly epidemiological update, 30 August 2021." 


\section{Supplementary Material}

\section{A Data}

\section{A.1 Description of dependent variables in survey}

Using the respondents' answers to selected survey questions, we create six dependent variables of interest:

1. The first dependent variable is based on the question "How likely do you think you are to catch the virus over the next year?". It is coded 1 for answers "Quite likely" and "Very likely", and 0 for answers "Very unlikely", "Quite unlikely", "Maybe 50-50".

2. The second dependent variable is based on the question "If you were to have Coronavirus, how confident are you that you would recover well?" where respondents have the following options: (a) "Very confident", (b) "Fairly confident", (c) "Not very confident", (d) "Not confident at all", and (e) "Don't know". We create a dichotomous variable that takes the value 1 if a respondent answered (a) or (b), and 0 if (c) or (d). We drop individuals who answered (e).

3. The third binary dependent variable is constructed from the question"Which of these do you think is the more likely outcome of this crisis over the next year?". It is coded 1 when respondents answered, "Many deaths, but not much worse than typical flu", and 0 otherwise, which includes options "Many millions dying throughout the world" and "Hundreds of millions dying throughout the world".

4. The fourth dependent variable is whether Covid is not taken seriously enough. It is based on the survey question: "Do you think overall people are taking Coronavirus?" We code this variable as 0 if the answer were "Too seriously" or "About right" and as 1 if "Not seriously enough". 
5. The fifth dependent variable is based on a survey question "Yesterday, did you leave your home for any reason at all?" and was recoded as 1 for people answering" Yes, for less than two hours" or "Yes, for more than two hours" and 0 if respondents did not leave the house.

6. The sixth dependent variable is created from a question "To what degree have you selfisolated?", which takes value 1 for responses "I am not going out at all" and 0 if respondents chose "I am going out much less but still a little", or "I go out just as often but only to open places", or "I have slightly reduced my time outside". 


\section{A.2 Summary statistics for survey}

Table A.1: Summary statistics

\begin{tabular}{llll}
\hline Variable & $\mathrm{N}$ & Mean & $\mathrm{SD}$ \\
\hline Likely to catch Covid & 88,773 & 0.2415 & 0.428 \\
Likely to recover from Covid & 95,615 & 0.6944 & 0.4607 \\
Covid not taken seriously & 109,300 & 0.5204 & 0.4995 \\
Covid like a flu & 94,992 & 0.282 & 0.4499 \\
Left home & 109,300 & 0.5751 & 0.4943 \\
Self-isolation & 86,959 & 0.2294 & 0.4205 \\
Work full-time & 109,300 & 0.5374 & 0.4986 \\
Work part-time & 109,300 & 0.1422 & 0.3492 \\
Retired & 109,300 & 0.2699 & 0.4439 \\
Unemployed & 109,300 & 0.0388 & 0.1931 \\
Student & 109,300 & 0.0494 & 0.2167 \\
Social grade & 109,300 & 0.4063 & 0.4912 \\
High education & 109,300 & 0.3030 & 0.4596 \\
Medium education & 109,300 & 0.4331 & 0.4955 \\
Low education level & 109,300 & 0.2638 & 0.4407 \\
Female & 109,300 & 0.5323 & 0.4990 \\
Age: 18 and 24 & 109,300 & 0.0944 & 0.2924 \\
Age: 25 and 34 & 109,300 & 0.1569 & 0.3637 \\
Age: 35 and 44 & 109,300 & 0.1666 & 0.3726 \\
Age: 45 and 54 & 109,300 & 0.1609 & 0.3674 \\
Age: 55 and 65 & 109,300 & 0.1647 & 0.3709 \\
Age 65 or over & 109,300 & 0.2566 & 0.4367 \\
Single & 108,573 & 0.3925 & 0.4883 \\
No children & 104,886 & 0.7433 & 0.4368 \\
1 child & 104,886 & 0.1190 & 0.3238 \\
2 children & 104,886 & 0.0998 & 0.2997 \\
3 children or more & 104,886 & 0.0379 & 0.1910 \\
Conservative & 76,231 & 0.3690 & 0.4825 \\
Green & 76,231 & 0.0503 & 0.2185 \\
Labour & 76,231 & 0.3924 & 0.4883 \\
Liberal Democrat & 76,231 & 0.1063 & 0.3082 \\
SNP & 76,231 & 0.0354 & 0.1849 \\
UKIP & 76,231 & 0.0466 & 0.2108 \\
\hline & & & \\
& & & \\
& & &
\end{tabular}




\section{A.3 Mobility data}

Two datasets have been merged for the second part of the empirical analysis. The first is the google mobility dataset which is extracted from the "Google COVID-19 Community Mobility Reports". This data captures individual movement trends by geographical units over time. Each observation on a particular day in a specific geographical unit reports the overall mobility on that day compared to a baseline day corresponding to a five-week period median value between 3rd January and 6th February 2020. For our analysis, we focus in the first instance on workplace mobility, but reproduce our results for transport mobility.

The second dataset is the electoral results for the most recent UK election in 2019. The electoral results by constituencies were taken from the House of Commons Library. For each constituency, this dataset reports the total number of valid and invalid votes as well as the absolute votes for each political party: Labour, Conservative, Green, Brexit party and Liberal Democrat.

Matching the two datasets is challenging due to multiple cases in the Google mobility data being reported for geographical units that are larger than the level of reporting for electoral results which is the constituency. One solution is to use the fact that Google mobility is often reported at the county level and constituencies in the election data are nested within counties. This makes it possible to identify all instances where there is data at county level in Google mobility dataset and then calculate the electoral score for this county using the lower level constituency absolute electoral results. Thus, we first add the total votes in each constituency of each party to create a county level total score for each political party. We then divide this total score by the sum of valid and invalid votes in this county. This provides us with the percentage of votes that each party in each county received. We then match this cross-county level electoral score to the Google mobility dataset. In total, there are 55 county level electoral scores in our dataset, and in most cases, the geographical units match exactly in both datasets: in 39 cases, there was an exact match between the 
electoral dataset and the geographical ID in the Google mobility dataset. In the remaining 16 cases, the match was either not exact or no possible. Table A.2 below shows the cases where the match was exact and hence straightforward, and the few cases where there is no possible matching. In some instances, the variables were named slightly differently but correspond to the same geographical unit (referred to as "other name" in the table). In other more complex cases, the county level electoral result had to be matched to multiple lower level sub-regional mobility data. Here, we average the mobility indicator of multiple google mobility geographical units that are nested in a county (referred to as "average" in the table). Finally, there are some cases with multiple counties within the geographical units in the Google mobility data where we must therefore aggregate the electoral results upwards (referred to as "aggregate" in the table):

1. In the first case, we average the Google mobility variables between "Cheshire East" and "Cheshire West and Chester" to match the county "Cheshire" from the electorate dataset.

2. The second case is averaging the Google mobility variables between "Blaenau Gwent" and "Vale of Glamorgan" to match the county "Gwent and Mid Glamorgan" from the electorate dataset.

3. The third case is averaging the six google mobility variables "Hereford" and "Worcestershire" to match the county "Hereford and Worcestershire" from the electorate dataset. 
Table A.2: Matching electoral and Google mobility datasets

\begin{tabular}{|c|c|c|c|}
\hline & $\begin{array}{l}\text { County name } \\
\text { in electoral dataset }\end{array}$ & $\begin{array}{l}\text { Sub region level } 1 \text { ID } \\
\text { in Google mobility data }\end{array}$ & Note \\
\hline 1 & Avon & & no match \\
\hline 2 & Bedfordshire & Central Bedfordshire & subregion \\
\hline 3 & Berkshire & West Berkshire & subregion \\
\hline 4 & Buckinghamshire & Buckinghamshire & exact \\
\hline 5 & Cambridgeshire & Cambridgeshire & exact \\
\hline 6 & Cheshire & $\begin{array}{l}\text { Cheshire East } \\
\text { Cheshire West and Chester }\end{array}$ & average \\
\hline 7 & Cleveland & Redcar and Cleveland & subregion \\
\hline 8 & Clwyd & & no match \\
\hline 9 & Cornwall & Cornwall & exact \\
\hline 10 & Cumbria & Cumbria & exact \\
\hline 11 & Derbyshire & Derbyshire & exact \\
\hline 12 & Devon & Devon & exact \\
\hline 13 & Dorset & Dorset & exact \\
\hline 14 & Durham & County Durham & different name \\
\hline 15 & Dyfed & & no match \\
\hline 16 & East Sussex & East Sussex & exact \\
\hline 17 & Essex & Essex & exact \\
\hline 18 & Gloucestershire & Gloucestershire & exact \\
\hline 19 & Greater Manchester & Greater Manchester & exact \\
\hline 20 & Gwent and Mid Glamorgan & $\begin{array}{l}\text { Blaenau Gwent } \\
\text { Vale of Glamorgan }\end{array}$ & average \\
\hline 21 & Gwynedd & Gwynedd & exact \\
\hline 22 & Hampshire & Hampshire & exact \\
\hline 23 & Hereford and Worcester & $\begin{array}{l}\text { Herefordshire } \\
\text { Worcestershire }\end{array}$ & average \\
\hline 24 & Hertfordshire & Hertfordshire & exact \\
\hline 25 & Humberside & & no match \\
\hline 26 & Isle of Wight & Isle of Wight & exact \\
\hline 27 & Kent & Kent & exact \\
\hline 28 & Lancashire & Lancashire & exact \\
\hline 29 & Leicestershire & Leicestershire & exact \\
\hline 30 & Lincolnshire & Lincolnshire & exact \\
\hline 31 & London & Greater London & different name \\
\hline 32 & Merseyside & Merseyside & exact \\
\hline 33 & Norfolk & Norfolk & exact \\
\hline 34 & North Yorkshire & North Yorkshire & exact \\
\hline 35 & Northamptonshire & Northamptonshire & exact \\
\hline
\end{tabular}




\begin{tabular}{llll}
\hline & $\begin{array}{l}\text { County name } \\
\text { in electoral dataset }\end{array}$ & $\begin{array}{l}\text { Sub region level 1 ID } \\
\text { in Google mobility data }\end{array}$ & Note \\
\hline 36 & Northern Ireland & Northumberland & no match \\
37 & Northumberland & Nottinghamshire & exact \\
38 & Nottinghamshire & Oxfordshire & exact \\
39 & Oxfordshire & Powys & exact \\
40 & Powys & Shropshire & exact \\
41 & Shropshire & Somerset & exact \\
42 & Somerset & Vale of Glamorgan & aggregate \\
43 & South Glamorgan & South Yorkshire & exact \\
44 & South Yorkshire & Staffordshire & exact \\
45 & Staffordshire & Suffolk & exact \\
46 & Suffolk & Surrey & exact \\
47 & Surrey & Tyne and Wear & exact \\
48 & Tyne and Wear & Warwickshire & exact \\
49 & Warwickshire & Vale of Glamorgan & aggregate \\
50 & West Glamorgan & West Midlands & exact \\
51 & West Midlands & West Sussex & exact \\
52 & West Sussex & West Yorkshire & exact \\
53 & West Yorkshire & Wiltshire & exact \\
54 & Wiltshire & & \\
\hline
\end{tabular}




\section{B Daily average response to survey questions}

Figure B.1: Home based work during COVID-19 pandemic

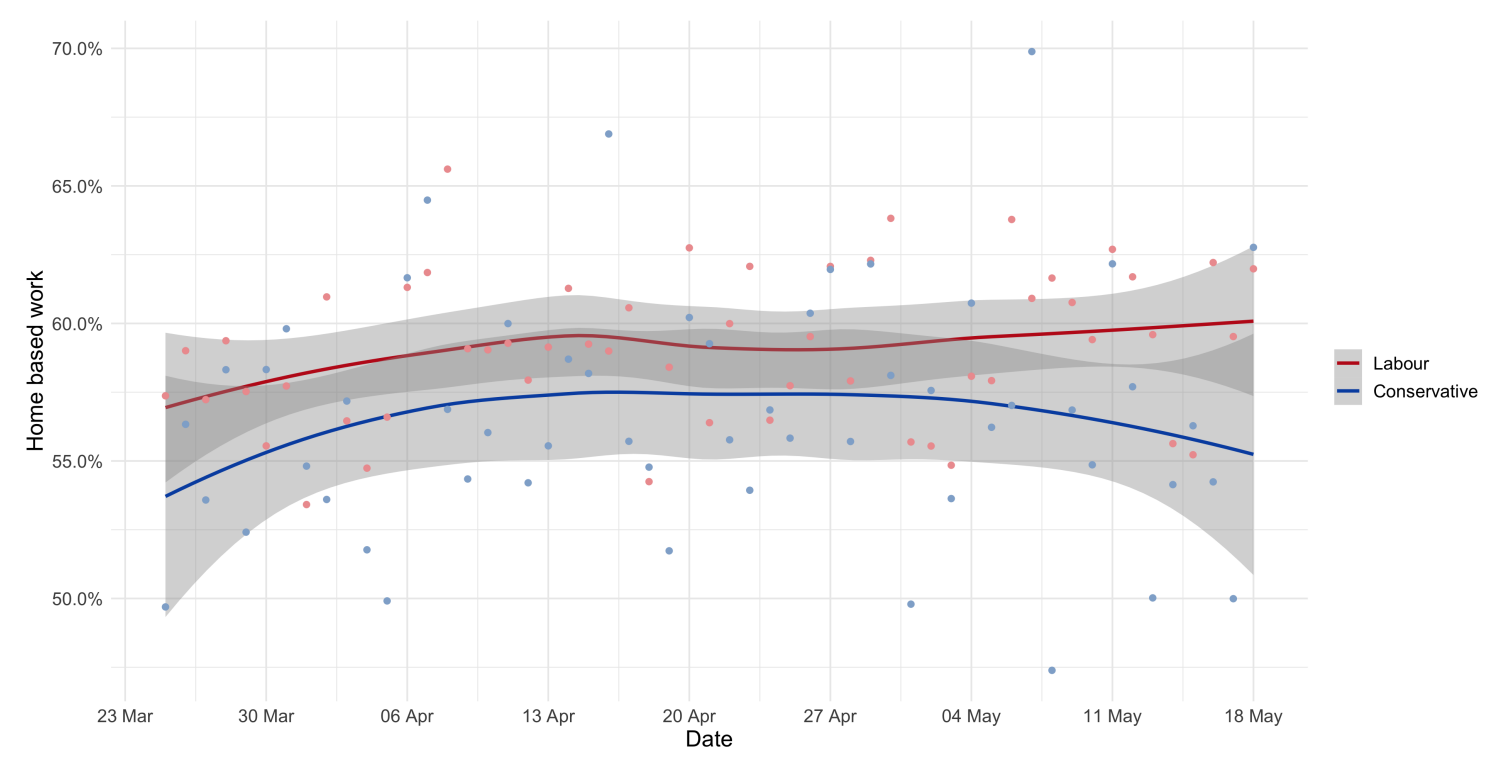

Note: The plot shows the average self-reported home-based work for each day for Labour (red) and Conservative (blue) voters. The plotted lines are loess smoothers (with ninety-five percent confidence intervals). 
Figure B.2: Loss of employment due to COVID-19 over

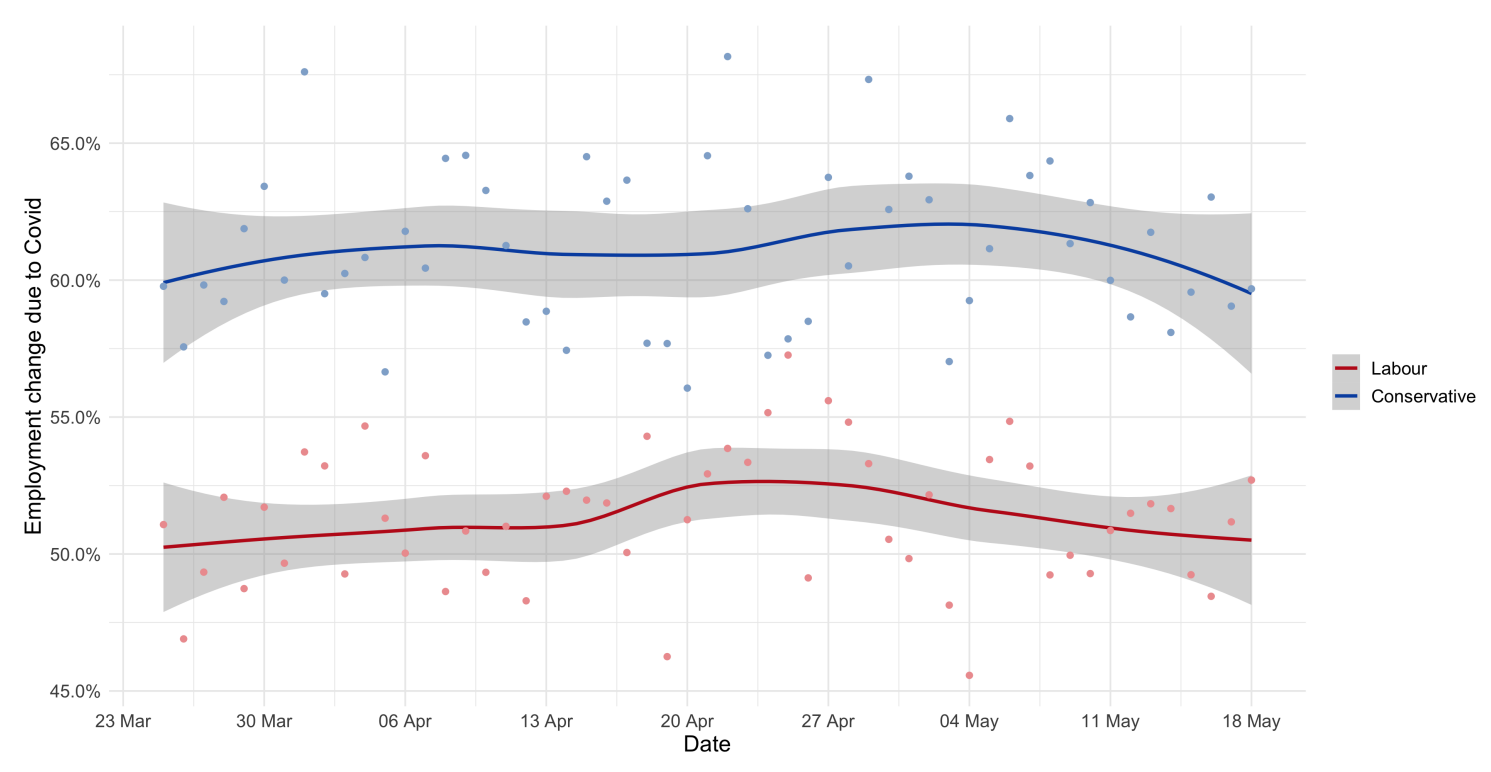

Note: The plot shows the average response whether respondent lost job due to Covid-19 for each day for Labour (red) and Conservative (blue) voters. The plotted lines are loess smoothers (with ninety-five percent confidence intervals).

Figure B.3: Self-reported heath below average for respondent?s age.

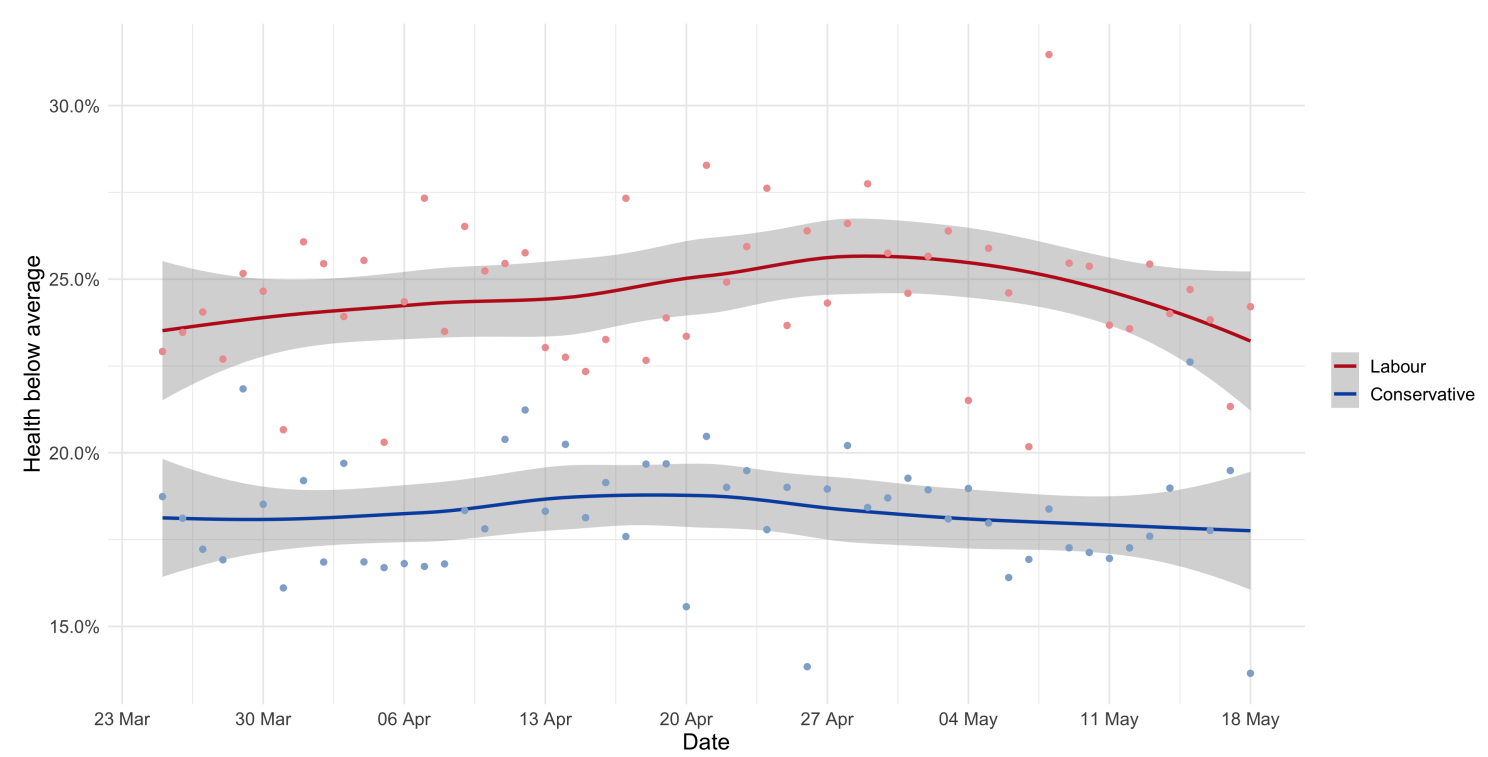

Note: The plot shows the average response whether respondent?s health is below average given their age for each day for Labour (red) and Conservative (blue) voters. The plotted lines are loess smoothers (with ninety-five percent confidence intervals). 
Figure B.4: Fear for own future during COVID-19 pandemic.

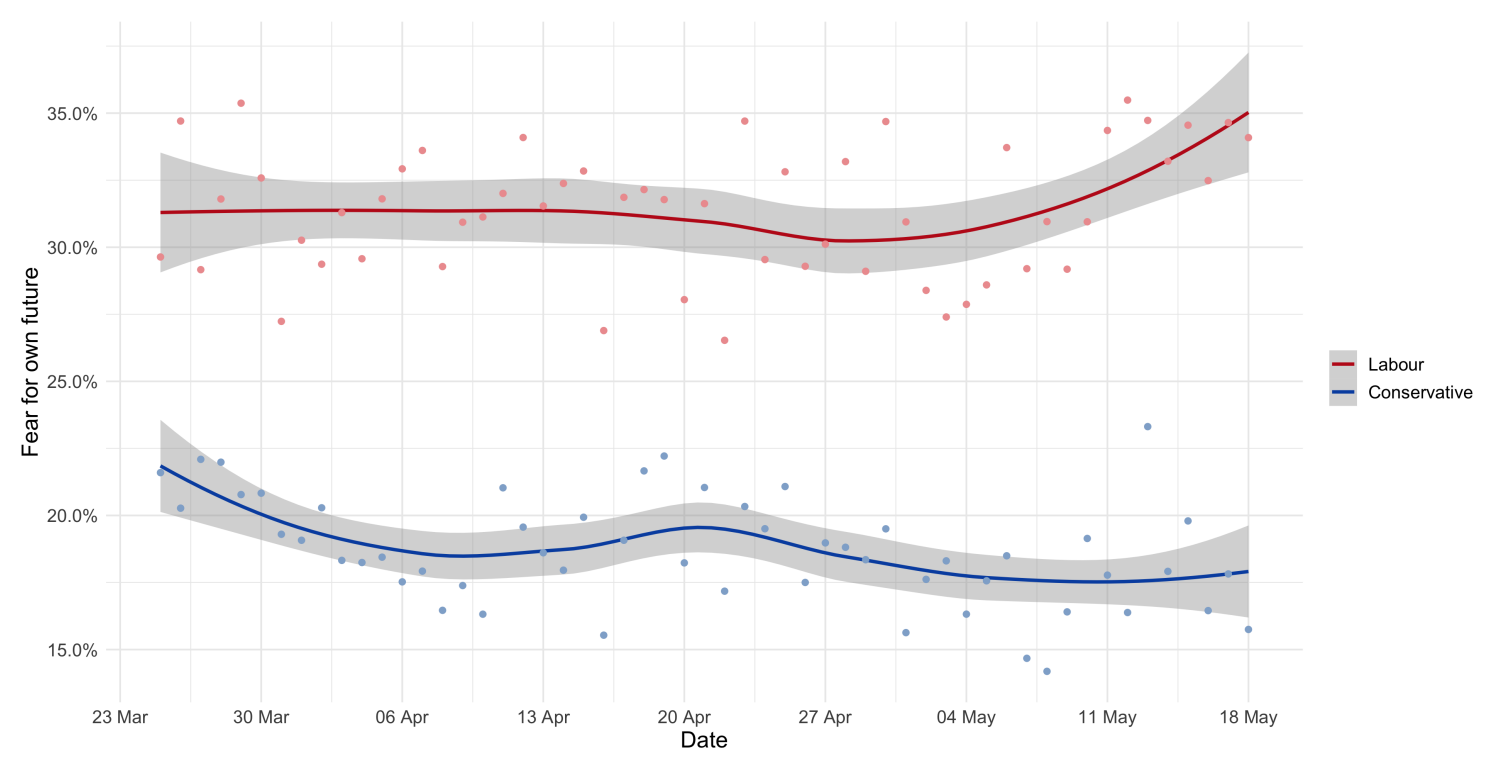

Note: The plot shows the average response whether respondent fears for their own future for each day for Labour (red) and Conservative (blue) voters. The plotted lines are loess smoothers (with ninety-five percent confidence intervals).

Figure B.5: Belief that economy will bounce back quickly after COVID-19 pandemic

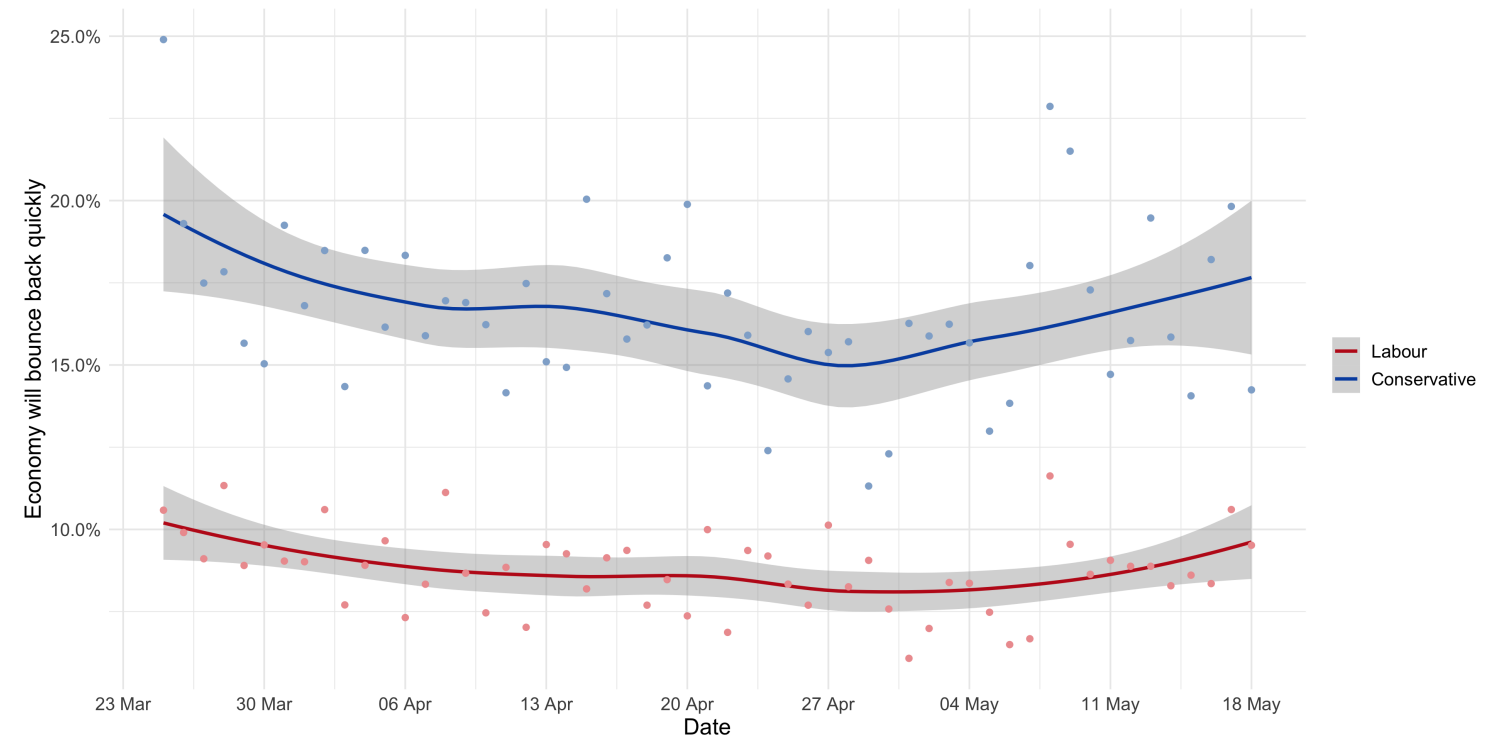

Note: The plot shows the average response whether respondent believe that the economy will bounce back quickly after COVID-19 pandemic for each day for Labour (red) and Conservative (blue) voters. The plotted lines are loess smoothers (with ninety-five percent confidence intervals). 
C Regression results 
Table C.3: Results from OLS regressions of Covid Attitudes

\begin{tabular}{|c|c|c|c|c|c|c|c|c|}
\hline Model & $(1)$ & $(2)$ & (3) & $(4)$ & $(5)$ & (6) & $(7)$ & (8) \\
\hline Dependent variable & $\begin{array}{l}\text { Covid Like } \\
\text { Flu }\end{array}$ & $\begin{array}{l}\text { Covid Like } \\
\text { Flu }\end{array}$ & $\begin{array}{l}\text { Covid Not } \\
\text { Taken Seriously }\end{array}$ & $\begin{array}{l}\text { Covid Not } \\
\text { Taken Seriously }\end{array}$ & $\begin{array}{l}\text { Likely } \\
\text { Recovery }\end{array}$ & $\begin{array}{l}\text { Likely } \\
\text { Recovery }\end{array}$ & $\begin{array}{l}\text { Likely to } \\
\text { Catch }\end{array}$ & $\begin{array}{l}\text { Likely to } \\
\text { Catch }\end{array}$ \\
\hline \multicolumn{9}{|c|}{ (reference: Conservative voters) } \\
\hline Green & $\begin{array}{l}-0.151^{* * *} \\
(0.00800)\end{array}$ & $\begin{array}{l}-0.149 * * * \\
(0.00840)\end{array}$ & $\begin{array}{l}0.104^{* * *} \\
(0.00883)\end{array}$ & $\begin{array}{l}0.0970^{* * * *} \\
(0.00903)\end{array}$ & $\begin{array}{l}0.0505^{* * *} \\
(0.00845)\end{array}$ & $\begin{array}{l}-0.0495 * * * \\
(0.00843)\end{array}$ & $\begin{array}{l}0.129 * * * \\
(0.00896)\end{array}$ & $\begin{array}{l}0.0640 * * * \\
(0.00920)\end{array}$ \\
\hline Labour & $\begin{array}{l}-0.157^{* * *} \\
(0.00411)\end{array}$ & $\begin{array}{l}-0.156^{* * *} \\
(0.00431)\end{array}$ & $\begin{array}{l}0.114^{* * *} \\
(0.00426)\end{array}$ & $\begin{array}{l}0.0947^{* * *} \\
(0.00442)\end{array}$ & $\begin{array}{l}-0.0138 * * * \\
(0.00438)\end{array}$ & $\begin{array}{l}-0.0767 * * * \\
(0.00433)\end{array}$ & $\begin{array}{l}0.0913 * * * \\
(0.00414)\end{array}$ & $\begin{array}{l}0.0521^{* * *} \\
(0.00421)\end{array}$ \\
\hline Liberal Democrat & $\begin{array}{l}-0.142^{* * *} \\
(0.00600)\end{array}$ & $\begin{array}{l}-0.140 * * * \\
(0.00605)\end{array}$ & $\begin{array}{l}-0.00284 \\
(0.00630)\end{array}$ & $\begin{array}{l}0.0143^{* *} \\
(0.00637)\end{array}$ & $\begin{array}{l}0.0333^{* * *} \\
(0.00639)\end{array}$ & $\begin{array}{l}-0.0340^{* * *} \\
(0.00620)\end{array}$ & $\begin{array}{l}0.102^{* * *} \\
(0.00615)\end{array}$ & $\begin{array}{l}0.0503^{* * *} \\
(0.00618)\end{array}$ \\
\hline None & $\begin{array}{l}-0.0561 * * * \\
(0.00566)\end{array}$ & $\begin{array}{l}-0.0652^{* * *} \\
(0.00576)\end{array}$ & $\begin{array}{l}0.0771^{* * *} \\
(0.00583)\end{array}$ & $\begin{array}{l}0.0520 * * * \\
(0.00591)\end{array}$ & $\begin{array}{l}0.0202^{* * *} \\
(0.00553)\end{array}$ & $\begin{array}{l}-0.0443^{* * *} \\
(0.00551)\end{array}$ & $\begin{array}{l}0.0538 * * * \\
(0.00530)\end{array}$ & $\begin{array}{l}0.0160^{* * *} \\
(0.00537)\end{array}$ \\
\hline Other & $\begin{array}{l}-0.0580 * * * \\
(0.0112)\end{array}$ & $\begin{array}{l}-0.0721^{* * *} \\
(0.0116)\end{array}$ & $\begin{array}{l}0.0509 * * * \\
(0.0112)\end{array}$ & $\begin{array}{l}0.0381^{* * *} \\
(0.0115)\end{array}$ & $\begin{array}{l}-0.0567^{* * *} \\
(0.0116)\end{array}$ & $\begin{array}{l}-0.0840 * * * \\
(0.0117)\end{array}$ & $\begin{array}{l}0.0858 * * * \\
(0.0107)\end{array}$ & $\begin{array}{l}0.0675^{* * *} \\
(0.0111)\end{array}$ \\
\hline Plaid Cymru & $\begin{array}{l}-0.130^{* * *} \\
(0.0237)\end{array}$ & $\begin{array}{l}-0.131^{* * *} \\
(0.0252)\end{array}$ & $\begin{array}{l}0.193^{* * *} \\
(0.0255)\end{array}$ & $\begin{array}{l}0.179^{* * * *} \\
(0.0263)\end{array}$ & $\begin{array}{c}-0.0483^{*} \\
(0.0274)\end{array}$ & $\begin{array}{l}-0.0753^{* * *} \\
(0.0273)\end{array}$ & $\begin{array}{l}0.0558 * * \\
(0.0253)\end{array}$ & $\begin{array}{l}0.0141 \\
(0.0264)\end{array}$ \\
\hline Scottish National Party & $\begin{array}{c}-0.144^{* * *} \\
(0.00954)\end{array}$ & $\begin{array}{l}-0.161^{* * *} \\
(0.0116)\end{array}$ & $\begin{array}{l}0.141^{* * *} \\
(0.0110)\end{array}$ & $\begin{array}{l}0.132^{* * *} \\
(0.0129)\end{array}$ & $\begin{array}{l}-0.0146 \\
(0.0104)\end{array}$ & $\begin{array}{l}-0.0932^{* * *} \\
(0.0117)\end{array}$ & $\begin{array}{l}0.0556^{* * *} \\
(0.00940)\end{array}$ & $\begin{array}{l}0.0194^{*} \\
(0.0115)\end{array}$ \\
\hline UK Independence Party & $\begin{array}{l}0.0595 * * * \\
(0.00971)\end{array}$ & $\begin{array}{l}0.0457^{* * *} \\
(0.00974)\end{array}$ & $\begin{array}{l}0.0648 * * * \\
(0.00933)\end{array}$ & $\begin{array}{l}0.0381^{* * *} \\
(0.00922)\end{array}$ & $\begin{array}{l}-0.0905^{* * *} \\
(0.00954)\end{array}$ & $\begin{array}{l}-0.0756^{* * *} \\
(0.00915)\end{array}$ & $\begin{array}{l}0.00409 \\
(0.00824)\end{array}$ & $\begin{array}{l}0.0240^{* * *} \\
(0.00837)\end{array}$ \\
\hline Constant & $\begin{array}{l}0.364^{* * *} \\
(0.00333)\end{array}$ & $\begin{array}{l}0.612^{* * *} \\
(0.0360)\end{array}$ & $\begin{array}{l}0.452^{* * *} \\
(0.00356)\end{array}$ & $\begin{array}{l}0.684^{* * *} \\
(0.0337)\end{array}$ & $\begin{array}{l}0.690 * * * \\
(0.00314)\end{array}$ & $\begin{array}{l}0.924^{* * *} \\
(0.0344)\end{array}$ & $\begin{array}{l}0.188^{* * *} \\
(0.00272)\end{array}$ & $\begin{array}{l}0.213^{* * *} \\
(0.0329)\end{array}$ \\
\hline Observations & 76,770 & 74,818 & 87,751 & 85,334 & 76,796 & 74,745 & 71,370 & 69,493 \\
\hline R-squared & 0.027 & 0.063 & 0.011 & 0.050 & 0.003 & 0.116 & 0.010 & 0.061 \\
\hline Controls & NO & YES & NO & YES & $\mathrm{NO}$ & YES & $\mathrm{NO}$ & YES \\
\hline
\end{tabular}

Note: This table displays the results from OLS regressions of different attitudes related to Covid-19 for different UK voters. Standard errors are clustered at the day and region levels. ${ }^{* * *} p<0.01,{ }^{* *} p<0.05,{ }^{*} p<0.1$. 
Table C.4: Results from OLS regressions of Covid Behaviours

\begin{tabular}{lllll}
\hline Model & $(1)$ & $(2)$ & $(3)$ & $(4)$ \\
\hline $\begin{array}{l}\text { Dependent variable } \\
\text { (reference: Conservative voters) }\end{array}$ & Left Home & Left Home & Self-Isolation & Self-Isolation \\
\hline Green & $0.0203^{* *}$ & 0.00397 & -0.0106 & -0.0116 \\
& $(0.00891)$ & $(0.00912)$ & $(0.00848)$ & $(0.00871)$ \\
Labour & $-0.0182^{* * *}$ & $-0.0210^{* * *}$ & $0.00773^{*}$ & 0.000737 \\
& $(0.00433)$ & $(0.00449)$ & $(0.00410)$ & $(0.00431)$ \\
Liberal Democrat & $0.0164^{* *}$ & -0.00517 & $-0.0139^{* *}$ & -0.00886 \\
& $(0.00645)$ & $(0.00656)$ & $(0.00571)$ & $(0.00585)$ \\
None & $-0.0171^{* * *}$ & $-0.0222^{* * *}$ & 0.00285 & 0.00123 \\
& $(0.00582)$ & $(0.00581)$ & $(0.00530)$ & $(0.00548)$ \\
Other & -0.00123 & -0.0158 & 0.0131 & 0.0151 \\
& $(0.0109)$ & $(0.0114)$ & $(0.0106)$ & $(0.0112)$ \\
Plaid Cymru & -0.0262 & -0.0134 & -0.0140 & $-0.0526^{*}$ \\
Scottish National Party & $(0.0275)$ & $(0.0278)$ & $(0.0267)$ & $(0.0276)$ \\
& -0.00354 & $-0.0580^{* * *}$ & -0.000877 & $0.0223^{*}$ \\
UK Independence Party & $(0.0102)$ & $(0.0123)$ & $(0.0102)$ & $(0.0115)$ \\
& $-0.0490^{* * *}$ & $-0.0374^{* * *}$ & $0.0314^{* * *}$ & $0.0232^{* *}$ \\
Constant & $(0.00933)$ & $(0.00925)$ & $(0.00958)$ & $(0.00957)$ \\
& $1.586^{* * *}$ & $1.510^{* * *}$ & $0.225^{* * *}$ & $0.434^{* * *}$ \\
Observations & $(0.00325)$ & $(0.0337)$ & $(0.00305)$ & $(0.0360)$ \\
R-squared & 87,751 & 85,334 & 70,101 & 68,314 \\
Controls & 0.001 & 0.038 & 0.000 & 0.028 \\
\hline \hline
\end{tabular}

Note: This table displays the results from OLS regressions of different behaviours related to Covid-19 for different UK voters. Standard errors are clustered at the day and region levels. ${ }^{* * *} p<0.01,{ }^{* *} p<0.05,{ }^{*} p<0.1$. 


\section{C.1 Additional coefficient plots}

Figure C.6: Coefficient plots of home based work, employment loss, good health, and fearing for own future

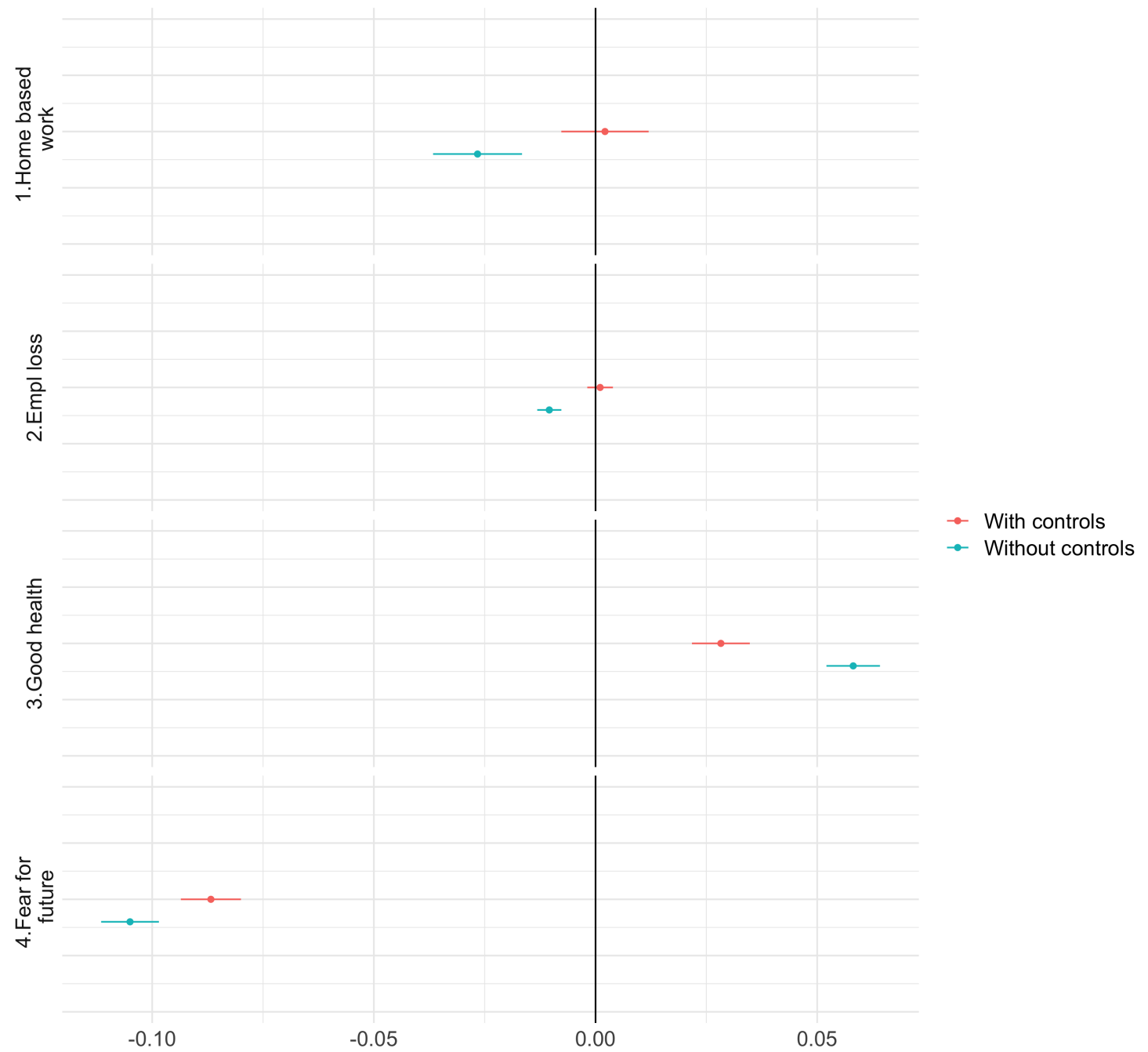

Note: The plot shows the coefficients (with 95\% confidence intervals) capturing the effect of being a Conservative voter as compared to other voters, extracted from regressions of attitudes towards Covid-19 on partisanship. The green estimates are for regressions without control variables. The red estimates are based on specifications with control variables. 


\section{Regression results for mobility data}

Figure D.7: The effect of national lockdown on change in mobility to workplace in counties with different levels of Conservative votes in previous national election

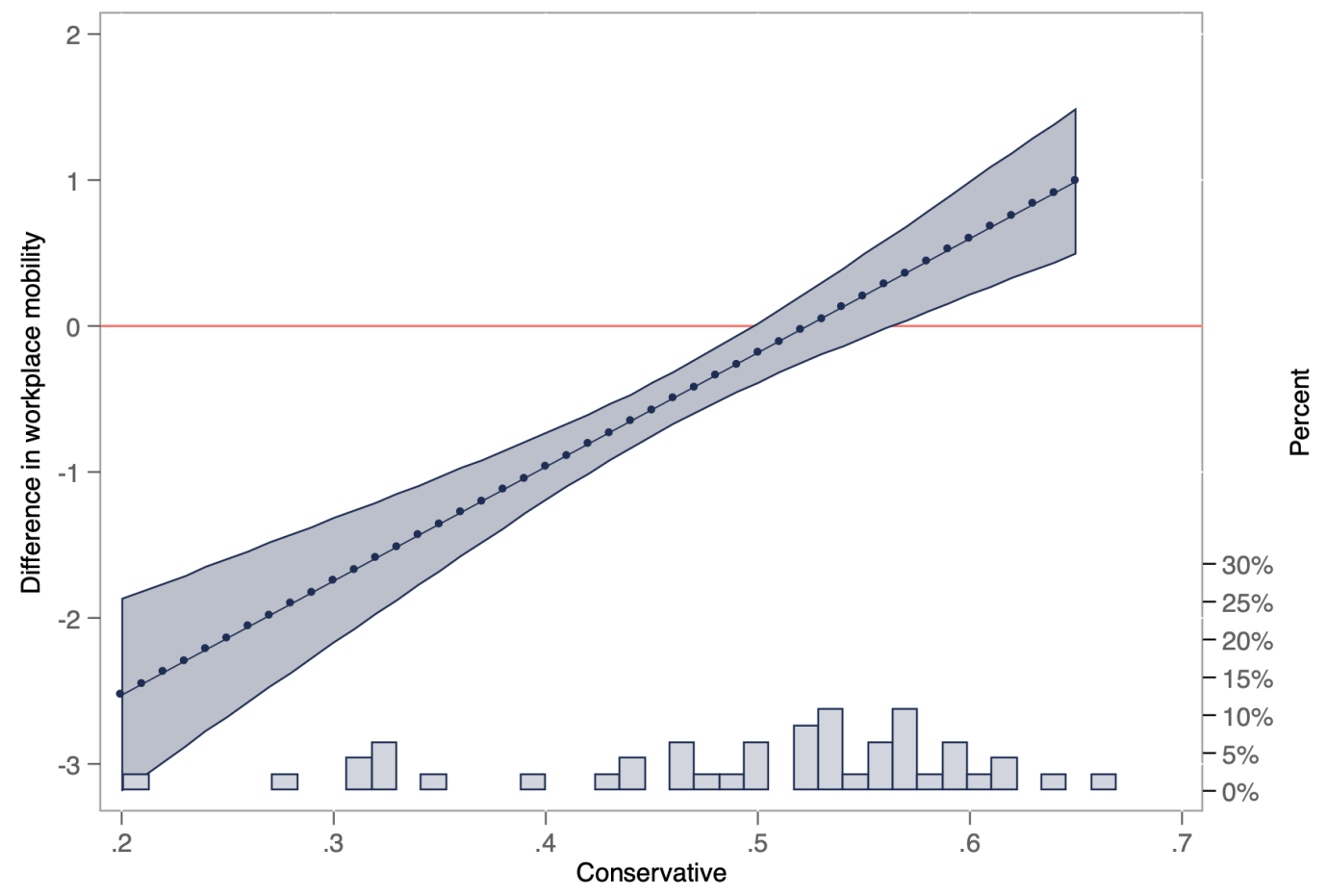

Note: Results from the specification described above using the google mobility data. Standard errors are clustered at daily level. 


\begin{tabular}{ll}
\hline Model & $(3)$ \\
\hline Dependent variable & Mobility \\
\hline Conservative & $-13.08^{* * *}$ \\
& $(1.143)$ \\
Lockdown & $-4.093^{* * *}$ \\
& $(0.574)$ \\
Conservative * Lockdown & $7.819^{* * *}$ \\
& $(1.234)$ \\
Log Covid-19 Cases & -0.0355 \\
& $(0.0408)$ \\
Trend & 0.00250 \\
& $(0.00202)$ \\
Trend Squared & $-1.02 \mathrm{e}-05$ \\
& $(7.20 \mathrm{e}-06)$ \\
Log House Prices & $7.413^{* * *}$ \\
& $(0.662)$ \\
Pop White Reg\% & $-124.1^{* * *}$ \\
& $(5.274)$ \\
Log Population Density & $-18.31^{* * *}$ \\
& $(0.946)$ \\
Log Wage & $20.39^{* * *}$ \\
& $(4.087)$ \\
Constant & $-76.32^{* * *}$ \\
& $(28.38)$ \\
\hline Observations & 7,581 \\
R-squared & 0.314 \\
Covid & YES \\
Trend & YES \\
Conion & YES \\
\hline \hline Note: This table displays & YES results from OLS \\
regressions of workplace & mobility for Conservative \\
counties in the UK. All & models include controls \\
as described in Methods & and Data section. \\
Standard errors are clustered at the day and \\
region levels. $* * * p<0.01$, & $* * p<0.05, * p<0.1$. \\
&
\end{tabular}


Table D.5: Robustness

\begin{tabular}{|c|c|c|c|c|c|}
\hline Model & $(1)$ & $(2)$ & (3) & (4) & $(5)$ \\
\hline Dependent variable & Mobility & Mobility & Mobility & Mobility & Mobility \\
\hline Conservative & $\begin{array}{l}-9.341^{* * *} \\
(1.931)\end{array}$ & $\begin{array}{l}-9.874^{* * *} \\
(1.947)\end{array}$ & $\begin{array}{l}-9.963^{* * *} \\
(1.977)\end{array}$ & $\begin{array}{l}-9.935^{* * *} \\
(2.007)\end{array}$ & $\begin{array}{l}-9.754^{\text {*** }} \\
(2.022)\end{array}$ \\
\hline Lockdown & $\begin{array}{l}-1.930 \\
(1.237)\end{array}$ & $\begin{array}{l}-2.465^{* *} \\
(1.198)\end{array}$ & $\begin{array}{l}-2.779^{* *} \\
(1.194)\end{array}$ & $\begin{array}{l}-2.811^{* *} \\
(1.196)\end{array}$ & $\begin{array}{l}-2.473^{* *} \\
(1.193)\end{array}$ \\
\hline Conservative ${ }^{*}$ Lockdown & $\begin{array}{l}5.674^{* *} \\
(2.373)\end{array}$ & $\begin{array}{l}5.866^{* * * *} \\
(2.273)\end{array}$ & $\begin{array}{l}5.810^{* * *} \\
(2.243)\end{array}$ & $\begin{array}{l}5.559^{* *} \\
(2.238)\end{array}$ & $\begin{array}{l}4.738^{* *} \\
(2.230)\end{array}$ \\
\hline Log Covid-19 Cases & $\begin{array}{l}1.130^{* * *} \\
(0.201)\end{array}$ & $\begin{array}{l}0.436^{* * *} \\
(0.136)\end{array}$ & $\begin{array}{l}0.0747 \\
(0.0972)\end{array}$ & $\begin{array}{l}-0.0689 \\
(0.0726)\end{array}$ & $\begin{array}{l}-0.0688 \\
(0.0662)\end{array}$ \\
\hline Trend & $\begin{array}{l}-0.290^{* * *} \\
(0.0488)\end{array}$ & $\begin{array}{l}-0.107^{* * *} \\
(0.0294)\end{array}$ & $\begin{array}{l}-0.0278 \\
(0.0177)\end{array}$ & $\begin{array}{l}-0.000783 \\
(0.0110)\end{array}$ & $\begin{array}{l}0.00272 \\
(0.00879)\end{array}$ \\
\hline Trend Squared & $\begin{array}{l}0.00219^{* * *} \\
(0.000370)\end{array}$ & $\begin{array}{l}0.000731^{* * *} \\
(0.000195)\end{array}$ & $\begin{array}{l}0.000177^{*} \\
(0.000103)\end{array}$ & $\begin{array}{l}6.97 \mathrm{e}-06 \\
(5.34 \mathrm{e}-05)\end{array}$ & $\begin{array}{l}-1.30 \mathrm{e}-05 \\
(3.76 \mathrm{e}-05)\end{array}$ \\
\hline Log House Prices & $\begin{array}{l}-0.954 \\
(1.374)\end{array}$ & $\begin{array}{l}0.719 \\
(1.263)\end{array}$ & $\begin{array}{l}1.845 \\
(1.188)\end{array}$ & $\begin{array}{l}3.140^{* * *} \\
(1.178)\end{array}$ & $\begin{array}{l}4.590^{* * *} \\
(1.134)\end{array}$ \\
\hline Pop White Reg\% & $\begin{array}{l}-89.88^{* * *} \\
(8.772)\end{array}$ & $\begin{array}{l}-97.58^{* * *} \\
(7.817)\end{array}$ & $\begin{array}{l}-97.86^{* * *} \\
(7.242)\end{array}$ & $\begin{array}{l}-94.78^{* * *} \\
(7.026)\end{array}$ & $\begin{array}{l}-89.54^{* * *} \\
(6.661)\end{array}$ \\
\hline Log Population Density & $\begin{array}{l}-15.93^{* * *} \\
(1.745)\end{array}$ & $\begin{array}{l}-16.02^{* * *} \\
(1.545)\end{array}$ & $\begin{array}{l}-15.26^{* * *} \\
(1.444)\end{array}$ & $\begin{array}{l}-14.38^{* * *} \\
(1.426)\end{array}$ & $\begin{array}{l}-13.12^{\text {*** }} \\
(1.357)\end{array}$ \\
\hline Log Wage & $\begin{array}{l}37.60^{* * *} \\
(8.864)\end{array}$ & $\begin{array}{l}35.06^{* * *} \\
(8.010)\end{array}$ & $\begin{array}{l}30.05^{* * *} \\
(7.521)\end{array}$ & $\begin{array}{l}22.93^{* * *} \\
(7.510)\end{array}$ & $\begin{array}{l}13.33^{*} \\
(7.196)\end{array}$ \\
\hline Constant & $\begin{array}{l}-195.1^{* * *} \\
(62.33)\end{array}$ & $\begin{array}{l}-182.9^{* * * *} \\
(56.41)\end{array}$ & $\begin{array}{l}-149.6^{* * *} \\
(52.82)\end{array}$ & $\begin{array}{l}-100.3^{*} \\
(52.49)\end{array}$ & $\begin{array}{l}-31.78 \\
(50.33)\end{array}$ \\
\hline$\overline{\text { Observations }}$ & 2,370 & 2,999 & 3,628 & 4,331 & 4,921 \\
\hline R-squared & 0.309 & 0.320 & 0.327 & 0.327 & 0.330 \\
\hline Covid & YES & YES & YES & YES & YES \\
\hline Trend & YES & YES & YES & YES & YES \\
\hline Region & YES & YES & YES & YES & YES \\
\hline Controls & YES & YES & YES & YES & YES \\
\hline Period & 100 & 125 & 150 & 175 & 200 \\
\hline
\end{tabular}

Note: This table displays the results from OLS regressions of workplace mobility for Conservative counties in the UK. All models include controls as described in Methods and Data section. Standard errors are clustered at the day and region levels. Robust standard errors in parentheses ${ }^{* * *} p<0.01,{ }^{* *} p<0.05,{ }^{*} p<0.1$. 


\begin{tabular}{|c|c|c|c|c|}
\hline Model & (6) & $(7)$ & (8) & $(9)$ \\
\hline Dependent variable & Mobility & Mobility & Mobility & Mobility \\
\hline Conservative & $\begin{array}{l}-10.42^{* * *} \\
(2.045)\end{array}$ & $\begin{array}{l}-11.27^{* * *} \\
(2.069)\end{array}$ & $\begin{array}{l}-12.22^{* * *} \\
(2.080)\end{array}$ & $\begin{array}{l}-13.08^{* * *} \\
(2.088)\end{array}$ \\
\hline Lockdown & $\begin{array}{l}-2.809^{* *} \\
(1.198)\end{array}$ & $\begin{array}{l}-3.572^{* * *} \\
(1.205)\end{array}$ & $\begin{array}{l}-4.066^{* * *} \\
(1.206)\end{array}$ & $\begin{array}{l}-4.093^{* * *} \\
(1.206)\end{array}$ \\
\hline Conservative ${ }^{*}$ Lockdown & $\begin{array}{l}5.392^{* *} \\
(2.238)\end{array}$ & $\begin{array}{l}6.918^{* * *} \\
(2.254)\end{array}$ & $\begin{array}{l}7.924^{* * *} \\
(2.250)\end{array}$ & $\begin{array}{l}7.819^{* * *} \\
(2.245)\end{array}$ \\
\hline Log Covid-19 Cases & $\begin{array}{l}-0.0552 \\
(0.0614)\end{array}$ & $\begin{array}{l}-0.0606 \\
(0.0604)\end{array}$ & $\begin{array}{l}-0.0414 \\
(0.0601)\end{array}$ & $\begin{array}{l}-0.0355 \\
(0.0578)\end{array}$ \\
\hline Trend & $\begin{array}{l}0.00168 \\
(0.00738)\end{array}$ & $\begin{array}{l}0.00193 \\
(0.00670)\end{array}$ & $\begin{array}{l}0.000400 \\
(0.00572)\end{array}$ & $\begin{array}{l}0.00250 \\
(0.00468)\end{array}$ \\
\hline Trend Squared & $\begin{array}{l}-7.40 \mathrm{e}-06 \\
(2.83 \mathrm{e}-05)\end{array}$ & $\begin{array}{l}-8.73 \mathrm{e}-06 \\
(2.43 \mathrm{e}-05)\end{array}$ & $\begin{array}{l}-2.21 \mathrm{e}-06 \\
(1.95 \mathrm{e}-05)\end{array}$ & $\begin{array}{l}-1.02 \mathrm{e}-05 \\
(1.48 \mathrm{e}-05)\end{array}$ \\
\hline Log House Prices & $\begin{array}{l}5.475^{* * *} \\
(1.092)\end{array}$ & $\begin{array}{l}6.359^{* * *} \\
(1.109)\end{array}$ & $\begin{array}{l}7.489^{* * *} \\
(1.109)\end{array}$ & $\begin{array}{l}7.413^{* * *} \\
(1.079)\end{array}$ \\
\hline Pop White Reg\% & $\begin{array}{l}-96.59^{* * *} \\
(6.432)\end{array}$ & $\begin{array}{l}-104.4^{* * *} \\
(6.472)\end{array}$ & $\begin{array}{l}-113.1^{* * *} \\
(6.497)\end{array}$ & $\begin{array}{l}-124.1^{* * *} \\
(6.351)\end{array}$ \\
\hline Log Population Density & $\begin{array}{l}-14.07^{* * *} \\
(1.307)\end{array}$ & $\begin{array}{l}-15.11^{* * *} \\
(1.324)\end{array}$ & $\begin{array}{l}-16.29^{* * *} \\
(1.329)\end{array}$ & $\begin{array}{l}-18.31^{* * *} \\
(1.299)\end{array}$ \\
\hline Log Wage & $\begin{array}{l}13.10^{*} \\
(6.910)\end{array}$ & $\begin{array}{l}13.53^{*} \\
(7.033)\end{array}$ & $\begin{array}{l}13.97^{* *} \\
(7.061)\end{array}$ & $\begin{array}{l}20.39 * * * \\
(6.892)\end{array}$ \\
\hline Constant & $\begin{array}{l}-28.19 \\
(48.36)\end{array}$ & $\begin{array}{l}-29.99 \\
(49.08)\end{array}$ & $\begin{array}{l}-33.29 \\
(49.23)\end{array}$ & $\begin{array}{l}-76.32 \\
(48.06)\end{array}$ \\
\hline$\overline{\text { Observations }}$ & 5,620 & 6,249 & 6,915 & 7,581 \\
\hline R-squared & 0.332 & 0.328 & 0.319 & 0.314 \\
\hline Covid & YES & YES & YES & YES \\
\hline Trend & YES & YES & YES & YES \\
\hline Region & YES & YES & YES & YES \\
\hline Controls & YES & YES & YES & YES \\
\hline Period & 225 & 250 & 275 & 300 \\
\hline
\end{tabular}

Note: This table displays the results from OLS regressions of workplace mobility for Conservative counties in the UK. All models include controls as described in Methods and Data section. Standard errors are clustered at the day and region levels. Robust standard errors in parentheses ${ }^{* * *} p<0.01,{ }^{* *} p<0.05,{ }^{*} p<0.1$. 
Figure D.8: The effect of national lockdown on change in transit mobility in counties with different levels of Conservative votes in previous national election

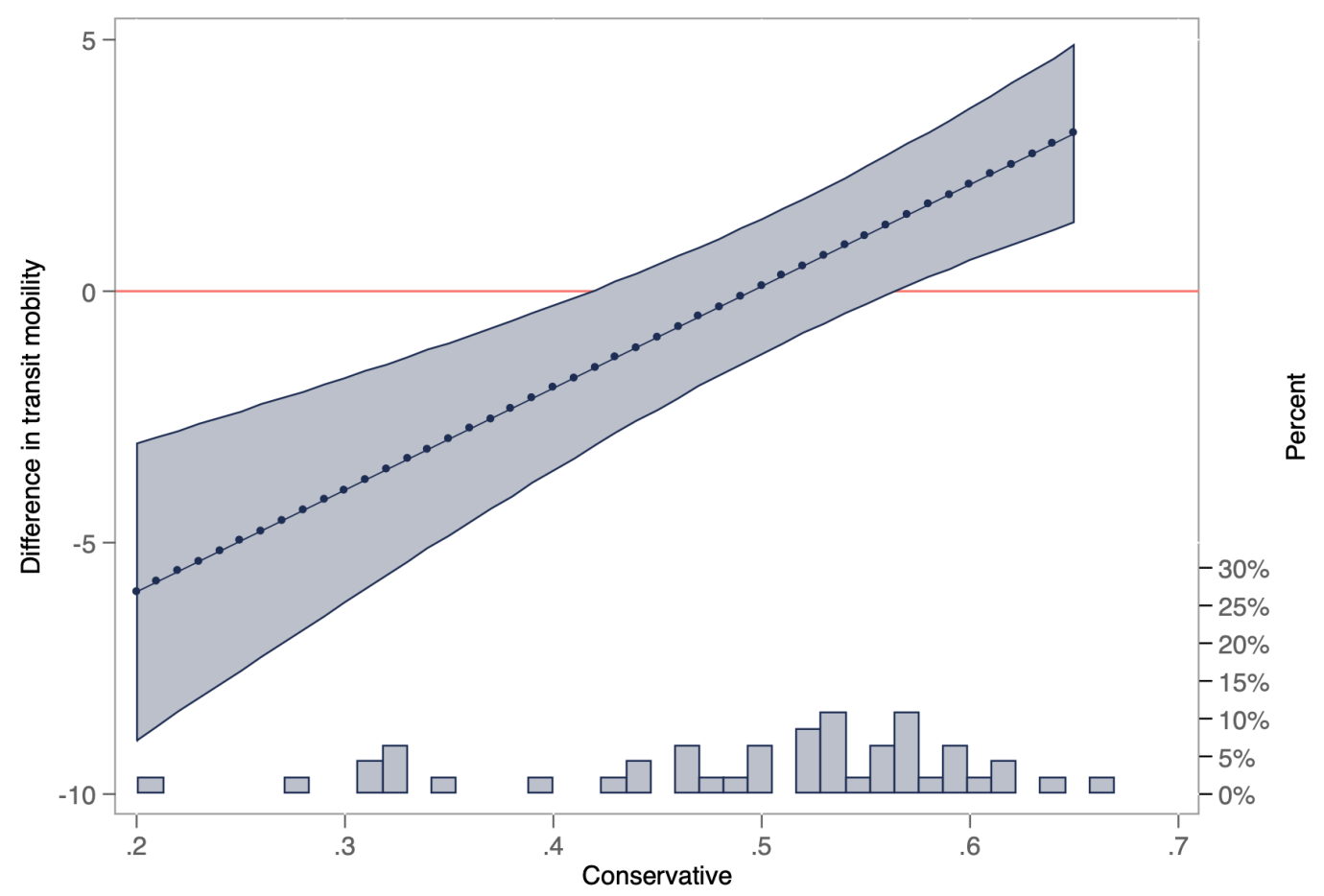

Note: Results from the specification described above using the google mobility data except the dependant variable is the change in transport mobility. Standard errors are clustered at day-region level. 


\section{E Random forests method}

To assess the predictive power of partisanship relative to other individual characteristics, we adopt a machine learning approach using the random forests method (Breiman, 2001). This method entails building many decision trees, and then only considering a subset of predictors for each split in a tree rather than a whole sample of predictors. It builds a large collection of decorrelated trees and then averages them. Following established practice, after estimating each model, we record the error rate in each classification and then use the following standard procedure to determine the importance of each variable.

We first select each variable with values $v_{1}, v_{2}, \ldots, v_{n}$ for each observation. Second, we permute values so that the first observation gets a value of $\mathrm{v}_{5}$, the second $\mathrm{v}_{3}$ and so on in a random way. Then we re-estimate our random forest and record the error rate again. We then repeat this procedure multiple times which yields an average error rate for the case where one variable has been permuted. As each value is assigned to the wrong observation, permutation effectively reduces the impact of each variable. By comparing the error rate to the benchmark case, we can in turn determine the importance of each variable. If the error rate is not significantly increased by the permutation, the variable is deemed not important to the prediction. We use this method to explore the importance of partisanship relative to other individual factors, and identify the factors that most strongly predict Covid-19 related beliefs and behaviours. 